\title{
Aliphatic-aromatic poly(ester-carbonate)s obtained from simple carbonate esters, $\alpha, \omega$-aliphatic diols and dimethyl terephthalate
}

\author{
M. Mazurek • T. Bruliński • K. Tomczyk • P. Parzuchowski • \\ Z. Florjańczyk • A. Plichta • G. Rokicki
}

Received: 10 September 2014 / Accepted: 1 January 2015 /Published online: 11 February 2015

(C) The Author(s) 2015. This article is published with open access at Springerlink.com

\begin{abstract}
Two reaction pathways for synthesis of high molar mass $\left(\mathrm{M}_{\mathrm{w}}\right.$ above $\left.50000 \mathrm{~g} / \mathrm{mol}\right)$ aliphatic-aromatic poly(estercarbonate)s were elaborated. Simple organic carbonates such as dimethyl carbonate or propylene carbonate were used as carbonate linkage sources and dimethyl terephthalate as the precursor of ester linkages. 1,4-Butanediol, 1,5-pentanediol, 1,6-hexanediol and 1,10-decanediol were used as diol monomers. To adjust the carbonate units content in the copolymer, solid alkylene bis(methylcarbonate) was used as a semiproduct instead of volatile dimethyl carbonate. In case of usage propylene carbonate as a starting material the process can be carried out in one pot without the need for isolation of the semiproduct. The obtained copolymers based on 1,4-butanediol, containing ca. $50 \mathrm{~mol} . \%$ of carbonate units exhibited better mechanical strength ( $37 \mathrm{MPa})$ than commercially available aliphatic-aromatic copolyester Ecoflex ${ }^{\circledR}$ keeping the thermal properties at the same level.
\end{abstract}

Keywords Aliphatic-aromatic poly(ester-carbonate)s . Dimethyl terephthalate $\cdot$ Dimethyl carbonate $\cdot$ Propylene carbonate

\section{Introduction}

Application of cheap and easily available carbon dioxide, directly or indirectly, as a monomer for polymer synthesis due to its inertness is a big challenge. In the 70-ties of the last century Inoue [1] as well as Kuran [2,3] used $\mathrm{CO}_{2}$ directly for

M. Mazurek $(\bowtie) \cdot$ T. Bruliński $\cdot$ K. Tomczyk $\cdot$ P. Parzuchowski •

Z. Florjańczyk $\cdot$ A. Plichta $\cdot$ G. Rokicki

Department of Chemistry, Chair of Polymer Chemistry and

Technology, Warsaw University of Technology, ul Noakowskiego 3, 00-664 Warsaw, Poland

e-mail: mmazurek@ch.pw.edu.pl copolymerization with oxiranes in the presence of organometallic catalysts based on $\mathrm{Zn}$ and Al leading to aliphatic polycarbonates. However, it has been difficult to find wide commercial application for polycarbonates obtained according to this process due to their low glass transition temperature and relatively poor mechanical properties. Recently, new catalysts such as cobalt complexes $[4,5]$, zinc adipate $[6,7]$ or a double metal cyanide complex [8] were investigated to improve the efficiency of copolymerization $\mathrm{CO}_{2}$ with oxiranes. The main advantage of aliphatic polycarbonates similarly to aliphatic polyesters is theirs biodegradability. In contrast to polyesters, biodegradation of aliphatic polycarbonates does not lead to the local increase of $\mathrm{pH}$ due to formation of hydroxyl groups and $\mathrm{CO}_{2}$ instead of $\mathrm{OH}$ and $\mathrm{COOH}$ groups. Additionally, the hydrolysis proceeds with a lower rate.

It was revealed that it is more convenient to use for synthesis of polycarbonates containing more than 3 carbon atom between carbonate linkages, monomers based on $\mathrm{CO}_{2}$ such as alkylene carbonates (ethylene carbonate (EC) or propylene carbonate (PC)) or dimethyl carbonate (DMC) [9-11].

Another attractive polymers which contain built-in $\mathrm{CO}_{2}$ are poly(ester-carbonate)s. These copolymers can be obtained according to ring opening copolymerization or by polycondensation methods. Usually polymers obtained by polycondensation exhibit poor mechanical properties due to relatively small molar mass. To obtain high molar mass poly(ester-carbonate)s copolymerization of cyclic esters (L-lactide, $\varepsilon$-caprolactone) with cyclic carbonate monomer-trimethylene carbonate (TMC) is usually carried out [12-14]. Besides TMC for copolymerization with cyclic esters other six-membered cyclic carbonates with different functional groups are also used [15-18].

Yang et al. prepared a series of new poly(ester-carbonate)s by a simple combination of polycondensation and ringopening-polymerization (ROP) of hydroxyl terminated poly(butylene succinate) macromonomers and various cyclic carbonate monomers [19]. 
In the synthesis of aliphatic poly(ester-carbonate)s according to step-growth polymerization mode phosgene derivatives usually were used as a source of carbonate linkages. Thus, Vincenzi et al. synthesized poly(ester-carbonate)s containing poly(oxyethylene) block applying PEG-bischloroformate [20]. Instead of phosgene or its derivatives for synthesis of aliphatic copoly(ester-carbonate)s by polycondensation diethyl carbonate or diphenyl carbonate [21] can be used. Also Chandure et al. used for synthesis of aliphatic poly(ester-carbonate)s diethyl carbonate, adipic acid and 1,3-propanediol. Poly(butylene carbonate-co-succinate), with low carbonate unit content $(<20 \mathrm{~mol} . \%)$, which can be used for poly(L-lactide) modification have been developed by Mitsubishi Gas Chemical Company [22].

More and coworkers obtained poly(ester-carbonate)s from ricinoleic acid, diol and diethyl carbonate [23]. Resultant dicarbonate monomer, 4-[(ethoxycarbonyl)oxy]butyl12-[(ethoxycarbonyl)oxy]octadec-9-enoate was polycondensed with various biobased diols to give poly(ester-carbonate)s. In the method proposed by Paturej and El Fray poly(ester- $b$-carbonate) was synthesized by coupling of oligo(trimethylene carbonate) diol with polyesterol based on dimerized fatty acid (Priplast 3192) by diisocyanate [24]. Biodegradable poly(ester-carbonate)s based on 1,3-propylene-co-1,4-cyclohexanedimethylene succinate were obtained from respective oligoesterols and phosgene [25]. To introduce carbonate linkages into the polymer backbone according to a polycondensation mode bis(p-nitrophenyl) carbonate can be applied instead of toxic phosgene [26, 27].

These biodegradable polymers can be applied in the production of medical materials such as sutures, implants and tissue scaffolds. Furthermore, polycarbonates have lower degradation rate than polyesters [28, 29], which would be advantageous in the applications where relatively higher stability is desired.

To achieve better mechanical properties, polymers, especially those obtained by polycondensation, should contain aromatic rings in their backbones. Thus, typical aliphaticaromatic polyester - poly(ethylene terephthalate) exhibits good mechanical strength even when its molar mass does not exceed $40000 \mathrm{~g} / \mathrm{mol}$. However, to achieve biodegradability aliphatic-aromatic random copolyester should contain less than $50 \mathrm{~mol}$.\% of aromatic dicarboxylic acid in acidic components and usually 1,4-butanediol instead of ethylene glycol (Ecoflex of BASF). Succinic or adipic acids are usually used as aliphatic dicarboxylic acids [30, 31]. When the numberaverage sequence of butylene phthalate units is lower than 3 the copolyester exhibit complete biodegradation [32]. Such copolyesters are used as packaging films as well as compost bags.

However, there is relatively little information concerning aliphatic-aromatic poly(ester-carbonate)s based on $\alpha, \omega$-diols, aromatic dicarboxylic acid and derivatives of carbonic acid.
This paper deals with the synthesis of poly(alkylene phthalateco-carbonate)s carried out by polycondensation method using dimethyl carbonate or propylene carbonate as precursors of carbonate linkages in the reaction with dimethyl terephthalate (DMT) and 1,4-butanediol, 1,5-pentanediol, 1,6-hexanediol and 1,10-decanediol. The macromolecular structures as well as mechanical and thermal properties of the obtained copolymers were characterized and discussed.

\section{Experimental section}

\section{Materials}

Dimethyl carbonate (DMC) (99\%), titanium(IV) butoxide $\left(\mathrm{Ti}(\mathrm{OBu})_{4}\right)(\geq 97 \%)$, (Sigma-Aldrich), propylene carbonate ( $\geq 99 \%$ \% (Merck) and n-Heptane ( $\geq 99 \%$ ) (Roth) were used as received. Dimethyl terephthalate ( $\geq 99 \%$ ) (Fluka Analytical) was dried for $24 \mathrm{~h}$ under pressure of $0.2 \mathrm{mbar}$ at room temperature before use. 1,10-Decanediol (98\%), 1,6hexanediol (97\%) (Aldrich), 1,5-pentanediol ( $\geq 97 \%$ ) (Fluka) and 1,4-butanediol (99\%) (Sigma-Aldrich) were dried for $8 \mathrm{~h}$ in $80^{\circ} \mathrm{C}$ under pressure of 20 mbar before use .

\section{Characterization techniques}

FTIR absorption spectra were recorded on a Biorad FTS-165 BIO-RAD spectrometer as $\mathrm{KBr}$ pellets. The measurements were carried in the range of $400-4000 \mathrm{~cm}^{-1}$ with a resolution of $2 \mathrm{~cm}^{-1}$.

${ }^{1} \mathrm{H}$ NMR and ${ }^{13} \mathrm{C}$ NMR spectra were recorded at room temperature on Varian VXR $400 \mathrm{MHz}$ spectrometer using tetramethylsilane as an internal reference and $\mathrm{CDCl}_{3}$ as solvent and analyzed with MestReNovav.6.2.0-7.238 (Mestrelab Research S.L) software. The carbonate unit content in the copolymers was calculated from ${ }^{1} \mathrm{H}$ NMR spectra according to our earlier report [33].

The molar mass and molar mass distribution were determined by GPC on a Viscotek system comprising GPCmax and TDA 305 triple detection unit (RI, IV, LS) equipped with one guard and two DVB Jordi gel columns (102-107, linear, mix bed) in $\mathrm{CH}_{2} \mathrm{Cl}_{2}$ as eluent at $35^{\circ} \mathrm{C}$ at a flow rate of $1.0 \mathrm{~mL} /$ min. Triple detection was used for determination of absolute molar mass and DI of condensation poly(ester-carbonate)s. Standard PS calibration was used in case of low molar mass products.

Matrix-assisted laser desorption/ionization time-of-flight mass spectroscopy (MALDI-TOF/MS) measurements were performed on a Bruker Ultra Flex MALDI TOF/ TOF spectrometer (Bremen, Germany) in a linear mode using DHB (2,5-dihydroxybenzoic acid) or HABA (2-(4'hydroxybenzeneazo)benzoic acid matrix and Bruker Peptide Calibration Standard (1047.19-3149.57 Da) as a calibrant and 
analyzed with flexAnalysis v.3.3 (Bruker Daltonik GmbH) and Polymerix v. 2.0 (Sierra Analytics Inc.) software.

Glass transition temperature $\left(\mathrm{T}_{\mathrm{g}}\right)$ was calculated from the inflection point in the break in the DSC heat flow curves. DSC studies were carried out using a TA Instruments DSC Q200 apparatus. Samples were heated in a temperature range from -50 to $200{ }^{\circ} \mathrm{C}$ with the heating rate $5 \mathrm{Kmin}^{-1}$, then cooled backward to $-50{ }^{\circ} \mathrm{C}$ with the heating rate of $10 \mathrm{Kmin}^{-1}$ and heated again to $200{ }^{\circ} \mathrm{C}$ with $20 \mathrm{Kmin}^{-1}$.

Thermal stability was studied by thermogravimetric analysis (TGA) performed using MOM Deriwatograph Q1500D. Heating rate was $10 \mathrm{Kmin}^{-1}$, scans were carried out starting at $20{ }^{\circ} \mathrm{C}$ up to $600{ }^{\circ} \mathrm{C}$. The reference substance was aluminum oxide.

Measurements of tensile strength were performed on Instron 5566 machine with a constant stretching rate of $5 \%$ of the length $/ \mathrm{min}$. For the data processing Bluehill software was used. Samples were prepared by compression in a hydraulic press at $170{ }^{\circ} \mathrm{C}$ and then cut into the form of dumbbell shape with the measuring section dimensions of $28 \mathrm{~mm}$ length $/ 4 \mathrm{~mm}$ width $/ 2 \mathrm{~mm}$ thickness. Tests were performed at room temperature. The values of Young's modulus (E), the relative elongation at break $\left(\varepsilon_{\text {break }}\right)$, tensile strength at break $\left(\varepsilon_{\text {break }}\right)$ and the stress at yield ( $\left.\sigma_{\text {yield }}\right)$ (if any) were calculated.

Synthesis of poly(tetramethylene terephthalate-co-carbonate) directly from dimethyl carbonate, 1,4-butanediol and dimethyl terephthalate

In a $250 \mathrm{~cm}^{3}$ three-neck round-bottomed flask equipped with a magnetic stirrer, thermometer, distilling condenser and nitrogen supply system, $30.63 \mathrm{~g}$ ( $0.3399 \mathrm{~mol})$ of 1,4-butanediol, $30.01 \mathrm{~g}(0.1545 \mathrm{~mol})$ of dimethyl terephthalate (DMT) and $0.17 \mathrm{~g}(0.5 \mathrm{mmol})$ of $\mathrm{Ti}(\mathrm{OBu})_{4}$ were placed. The reaction was carried out at $150-220{ }^{\circ} \mathrm{C}$ under atmospheric pressure with a nitrogen flow, until no methanol was observed in the distillate (the refractive index was measured). After removing almost whole theoretical amount of methanol $(2 \mathrm{~h})$ the reaction temperature was reduced to $95-115^{\circ} \mathrm{C}$ and $83.50 \mathrm{~g}(0.9270 \mathrm{~mol})$ DMC was added and the polycondensation was continued under reflux without removing methanol from the reaction mixture for $2 \mathrm{~h}$. Then, methanol/DMC was gradually distilled off using a long Vigreoux column. When the content of methanol in the distillate was lower than $3 \%$ (refractive index) the reaction again was carried out under reflux for $2 \mathrm{~h}$ to generate the next portion of methanol. This procedure was repeated 3 times.

Alternatively, DMC was introduced into reaction mixture in 3 portions and the process was carried out according to the above mentioned manner.
TC4-9: ${ }^{1} \mathrm{H}$ NMR $\left(400 \mathrm{MHz}, d-\mathrm{CHCl}_{3}\right): \delta(\mathrm{ppm})=8.03(\mathrm{~s}$, $4 \mathrm{H}), 4.38(\mathrm{t}, 4 \mathrm{H}, J=5.9 \mathrm{~Hz}), 4.35(\mathrm{t}, 4 \mathrm{H}, J=5.9 \mathrm{~Hz}), 4.13(\mathrm{t}$, $4 \mathrm{H}, J=5.9 \mathrm{~Hz}$ ), 4.10 (t, $4 \mathrm{H}, J=5.8 \mathrm{~Hz}$ ), 3.71-3.66 (two overlapping triplets, $8 \mathrm{H}, J=6.4,6.3 \mathrm{~Hz}$ ), 1.81 (bs, $4 \mathrm{H}$ ), 1.71 (bs, $8 \mathrm{H}), 1.60$ (bs, $4 \mathrm{H})$.

FTIR (KBr): 2960, 2859, 1743, 1442, 1320, 1258, 1022, $935,792 \mathrm{~cm}^{-1}$.

\section{Synthesis of alkylene bis(methylcarbonate)s}

Alkylene bis(methylcarbonate)s (BMC) were obtained in reaction of 6 -fold molar excess of DMC with $\alpha, \omega$-diol. The procedure was described by us earlier [10]. $\mathrm{Ti}(\mathrm{OBu})_{4}$ $(0.1 \mathrm{~mol} . \%)$ was used as a catalyst. BMC means alkylene bis(methyl carbonate) and the number after signifies the length of hydrocarbon chain in the $\alpha, \omega$-diol, for example BMC4 means tetramethylene bis(methylcarbonate).

BMC4: ${ }^{1} \mathrm{H}$ NMR $\left(400 \mathrm{MHz}, d-\mathrm{CHCl}_{3}\right): \delta(\mathrm{ppm})=4.15(\mathrm{t}$, $4 \mathrm{H}, J=6.2 \mathrm{~Hz}), 3.77$ (s, 6H), 1.74 (bs, $4 \mathrm{H})$.

BMC5: ${ }^{1} \mathrm{H}$ NMR $\left(400 \mathrm{MHz}, d-\mathrm{CHCl}_{3}\right): \delta(\mathrm{ppm})=4.06(\mathrm{t}$, 4H, $J=6.7 \mathrm{~Hz}$ ), 3.69 (s, 6H), 1.63 (bs, 4H), 1.39 (bs, 2H).

BMC6: ${ }^{1} \mathrm{H}$ NMR $\left(400 \mathrm{MHz}, d-\mathrm{CHCl}_{3}\right): \delta(\mathrm{ppm})=4.09(\mathrm{t}$, $4 \mathrm{H}, J=6.6 \mathrm{~Hz}$ ), 3.75 (s, 6H), 1.70 (bs, 4H), 1.34 (bs, 4H).

BMC10: ${ }^{1} \mathrm{H}$ NMR $\left(400 \mathrm{MHz}, d-\mathrm{CHCl}_{3}\right): \delta(\mathrm{ppm})=4.11(\mathrm{t}$, 4H, J=6.8 Hz), 3.77 (s, 6H), 1.66 (bs, 4H), 1.34 (bs, 4H,), 1.28 (bs, $8 \mathrm{H})$.

FTIR (KBr): 2962, 2860, 1745, 1444, 1323, 1260, 1027, $936,793 \mathrm{~cm}^{-1}$.

Synthesis of poly(tetramethylene terephthalate-co-carbonate) from butylene bis(methylcarbonate), DMT and 1,4-butanediol

In a $250 \mathrm{~cm}^{3}$ three-neck round-bottomed flask equipped with a magnetic stirrer, thermometer, distilling condenser and nitrogen supply system, $75.53 \mathrm{~g}(0.8381 \mathrm{~mol})$ of 1,4-butanediol, $43.63 \mathrm{~g}(0.1983 \mathrm{~mol})$ of BMC4, $69.96 \mathrm{~g}(0.3605 \mathrm{~mol})$ of dimethyl terephthalate (DMT) and $0.19 \mathrm{~g}(0.6 \mathrm{mmol})$ of $\mathrm{Ti}(\mathrm{OBu})_{4}$ were placed. The reaction was carried out at 180 $190{ }^{\circ} \mathrm{C}$ for $8 \mathrm{~h}$ under atmospheric pressure with a nitrogen flow, until no methanol was observed in the distillate (the refractive index was measured). Then, the reaction was continued under reduced pressure: $20 \mathrm{mbar}$ $\left(190{ }^{\circ} \mathrm{C}, 2 \mathrm{~h}\right), 0.2 \mathrm{mbar}\left(190{ }^{\circ} \mathrm{C}, 2.5 \mathrm{~h}\right)$ and $0.1 \mathrm{mbar}$ $\left(215^{\circ} \mathrm{C}, 8 \mathrm{~h}\right) .123 .70 \mathrm{~g}$ of the poly(tetramethylene terephthalate-co-carbonate) (TC4-50) was obtained as an semicrystalline colorless solid with $\mathrm{M}_{\mathrm{n}}=8260$ containing $50 \mathrm{~mol} . \%$ of butylene carbonate units.

Poly(alkylene terephthalate-co-carbonate)s based on 1,6-hexanediol, 1,5-pentanediol and 1,4-butanediol/1,5pentanediol mixture (1,4-BDO:1,5-PDO $=1: 1$ and BMC4:BMC5=1:1) were obtained in the same manner. Products were white semicrystalline solids. 
TC means aliphatic-aromatic poly(alkylene terephthalate-co-carbonate) and the number after signifies the length of hydrocarbon chain in the $\alpha, \omega$-diol and content of carbonate units, respectively. For example TC4-50 means poly(tetramethylene terephthalate-co-carbonate) with $50 \mathrm{~mol} \%$ of carbonate units.

TC4-50: ${ }^{1} \mathrm{H}$ NMR $\left(400 \mathrm{MHz}, d-\mathrm{CHCl}_{3}\right): \delta(\mathrm{ppm})=8.09(\mathrm{~s}$, $4 \mathrm{H}), 4.43(\mathrm{t}, 4 \mathrm{H}, J=6.2 \mathrm{~Hz}), 4.37(\mathrm{t}, 4 \mathrm{H}, J=6.2 \mathrm{~Hz}), 4.21(\mathrm{t}$, $4 \mathrm{H}, J=6.2 \mathrm{~Hz}), 4.17(\mathrm{t}, 4 \mathrm{H}, J=6.2 \mathrm{~Hz}), 3.73(\mathrm{t}, 4 \mathrm{H}, J=6.0 \mathrm{~Hz})$, 3.68 (t, 4H, J=6.0 Hz), 1.87 (bs, 4H), 1.76 (bs, 8H), 1.66 (bs, $4 \mathrm{H})$.

TC4/5-67: ${ }^{1} \mathrm{H}$ NMR (400 MHz, d-CHCl 3$): \delta(p p m)=8.07$ (bs, 4H), $4.42(\mathrm{t}, 4 \mathrm{H}, J=6.4 \mathrm{~Hz}), 4.39-4.32(\mathrm{~m}, 8 \mathrm{H})$, $4.20(\mathrm{t}, 4 \mathrm{H}, J=5.9 \mathrm{~Hz}), 4.16-4.12(\mathrm{~m}, 8 \mathrm{H}), 3.74-3.63(\mathrm{~m}$, $8 \mathrm{H}), 1.96-1.85(\mathrm{~m}, 8 \mathrm{H}), 1.79-1.72(\mathrm{~m}, 8 \mathrm{H}), 1.72-1.64$ (m, 8H), 1.55 (bs, 4H), 1.46 (bs, 4H).

TC5-49: ${ }^{1} \mathrm{H}$ NMR (400 MHz, d-CHCl 3$): \delta(p p m)=8.08$ (bs, 4H), 4.36 (two overlapping triplets, $8 \mathrm{H}, J=7.8,6.6 \mathrm{~Hz}$ ), 4.14 (two overlapping triplets, $8 \mathrm{H}, J=8.1,6.5 \mathrm{~Hz}$ ), 3.67 (bs, $8 \mathrm{H}), 1.77$ (bs, 4H), 1.71-1.57 (m, 16H), 1.57-1.44 (m, 8H), $1.44-1.30(\mathrm{~m}, 8 \mathrm{H})$.

TC6-47: ${ }^{1} \mathrm{H}$ NMR (400 MHz, d-CHCl $\left.{ }_{3}\right): \delta(p p m)=8.07$ (bs, $4 \mathrm{H}$ ), 4.34 (two overlapping triplets, $8 \mathrm{H}, J_{1}=7.9 \mathrm{~Hz}, J_{2}=$ $6.6 \mathrm{~Hz}$ ), 4.12 (two overlapping triplets, $8 \mathrm{H}, J_{1}=8.5 \mathrm{~Hz}, J_{2}=$ $6.9 \mathrm{~Hz}$ ), 3.64 (two overlapping triplets, $8 \mathrm{H}, J_{1}=7.7 \mathrm{~Hz}, J_{2}=$ $6.5 \mathrm{~Hz}$ ), 1.79 (bs, 8H), 1.67 (bs, 8H), 1.53 (bs, 4H), 1.47 (bs, 4H), 1.40 (bs, 8H).

FTIR (KBr): 2963, 2902, 1744, 1716, 1247, 1119, 928, $728 \mathrm{~cm}^{-1}$

Synthesis of poly(tetramethylene terephthalate-co-carbonate) on larger scale

The synthesis of poly(tetramethylene terephthalate-cocarbonate) was carried out on larger scale in a stainless steel reactor of $2 \mathrm{dm}^{3}$. The reactor was equipped with a mechanical stirrer, a distillation system, a heatingcooling mantle, nitrogen inlet and outlet and oil vacuum pump. The reactor contained 4 electrically powered heating zones controlled automatically (trigger, bottom, top, cover). Based on the power consumption of the mechanical stirrer the information about increase of the reaction mixture viscosity during the synthesis was possible to monitor. $389.91 \mathrm{~g}(2.0080 \mathrm{~mol})$ of dimethyl terephthalate, $394.82 \mathrm{~g}(4.3811 \mathrm{~mol})$ of 1,4-butanediol, $200.80 \mathrm{~g}(0.9127 \mathrm{~mol})$ of BMC4 were placed. Reaction was carried out at $150-220{ }^{\circ} \mathrm{C}$ first under atmospheric pressure with nitrogen flow until no methanol was observed in distillate. The temperature was increased to $220{ }^{\circ} \mathrm{C}$ slowly. Than the process was continued under reduced pressure of 0.3 mbar until the viscosity of the product indicated a significant increase in molar mass, and when no further evolution of 1,4-butanediol was observed. $695.91 \mathrm{~g}$ of poly(tetramethylene terephthalate-co-carbonate) as a white solid with $\mathrm{M}_{\mathrm{n}}=24790$ and 46 mol.\% of carbonate units was obtained.

TC4-46: ${ }^{1} \mathrm{H}$ NMR (400 MHz, $\left.d-\mathrm{CHCl}_{3}\right): \delta(\mathrm{ppm})=8.08$ (4H, bs), $4.43(\mathrm{t}, 4 \mathrm{H}, J=5.8 \mathrm{~Hz}), 4.38(\mathrm{t}, 4 \mathrm{H}, J=5.9 \mathrm{~Hz})$, $4.21(\mathrm{t}, 4 \mathrm{H}, J=6.1 \mathrm{~Hz}), 4.17(\mathrm{t}, 4 \mathrm{H}, J=5.8 \mathrm{~Hz}), 3.71(\mathrm{t}, 4 \mathrm{H}$, $J=6.4 \mathrm{~Hz}), 3.68$ (t, 4H, $J=6.3 \mathrm{~Hz}), 1.97(4 \mathrm{H}, \mathrm{bs}), 1.88(8 \mathrm{H}$, bs), $1.77(4 \mathrm{H}, \mathrm{bs})$.

Synthesis of poly(decamethylene terephthalate-co-carbonate)

In a $100 \mathrm{~cm}^{3}$ three-neck round-bottomed flask equipped with a magnetic stirrer, thermometer, distilling condenser and nitrogen supply system, $38.48 \mathrm{~g}(0.2208 \mathrm{~mol})$ of $1,10-$ decanediol, $22.23 \mathrm{~g}(0.0783 \mathrm{~mol})$ of BMC10, $9.95 \mathrm{~g}$ $(0.1104 \mathrm{~mol})$ of 1,4-butanediol, $27.66 \mathrm{~g}(0.1425 \mathrm{~mol})$ of dimethyl terephthalate (DMT) and $0.06 \mathrm{~g}(0.2 \mathrm{mmol})$ of $\mathrm{Ti}(\mathrm{OBu})_{4}$ were placed. The reaction was carried out at 180-190 ${ }^{\circ} \mathrm{C}$ for $8 \mathrm{~h}$ under atmospheric pressure with a nitrogen flow, until no methanol was observed in the distillate (the refractive index was measured). Then, the reaction was continued under reduced pressure: 20 mbar $\left(190{ }^{\circ} \mathrm{C}, 2 \mathrm{~h}\right), 0.2$ mbar $\left(190{ }^{\circ} \mathrm{C}, 2.5 \mathrm{~h}\right)$ and $0.1 \mathrm{mbar}$ $\left(215{ }^{\circ} \mathrm{C}, 8 \mathrm{~h}\right) .45 .6 \mathrm{~g}$ of the poly(decamethylene-cotetramethylene terephthalate-co-carbonate) (TC10/4-50) was obtained as a white solid with $\mathrm{M}_{\mathrm{n}}=17320$ containing ca. $50 \mathrm{~mol} \%$ of carbonate units.

TC10/4-50: ${ }^{1} \mathrm{H}$ NMR $\left(400 \mathrm{MHz}, d-\mathrm{CHCl}_{3}\right): \delta(\mathrm{ppm})=8.09$ (bs, 4H), 4.43 (t, 4H, $J=5.8 \mathrm{~Hz}), 4.33$ (t, 8H, $J=6.7 \mathrm{~Hz}), 4.20$ (t, $4 \mathrm{H}, J=5.9 \mathrm{~Hz}$ ), 4.11 (two overlapping triplets, $8 \mathrm{H}, J=8.4$, $6.7 \mathrm{~Hz}$ ), 3.63 (two overlapping triplets, $8 \mathrm{H}, J=7.8,6.6 \mathrm{~Hz}$ ), 1.87 (bs, 4H), 1.77 (bs, 4H), 1.65 (bs, 4H), 1.42 (bs, 4H), 1.42$1.25(\mathrm{~m}, 16 \mathrm{H})$.

Poly(alkylene terephthalate-co-carbonate) based on 1,6hexanediol was obtained in the same manner. $56.9 \mathrm{~g}$ of the poly(hexamethylene-co-tetramethylene terephthalate-co-carbonate) (TC6/4-49) was obtained as an white semicrystalline solid with $\mathrm{M}_{\mathrm{n}}=18400$ containing 49 mol.\% of carbonate units.

(TC6/4-49): ${ }^{1} \mathrm{H}$ NMR $\left(400 \mathrm{MHz}, d-\mathrm{CHCl}_{3}\right): \delta(\mathrm{ppm})=8.07$ (4H, bs), 4.42 (t, $4 \mathrm{H}, J=5.7 \mathrm{~Hz}$ ), 4.34 (two overlapping triplets, $8 \mathrm{H}, J=8.2 \mathrm{~Hz}, 6.6 \mathrm{~Hz}$ ), 4.20 (t, 4H, $J=5.8 \mathrm{~Hz}$ ), 4.13 (two overlapping triplets, $8 \mathrm{H}, J=8.1,6.4 \mathrm{~Hz}), 3.65(\mathrm{bs}, 4 \mathrm{H}), 1.79$ (4H, bs), 1.69 (4H, bs), 1.53 (2H, bs), 1.47 (4H, bs), 1.40 (2H, bs).

Synthesis of poly(tetramethylene terephthalate-co-carbonate) based on propylene carbonate

Poly(tetramethylene terephthalate-co-carbonate) was alternatively obtained from propylene carbonate as a source of carbonate linkages according to the procedure described by us earlier [37]. 
In a $250 \mathrm{~cm}^{3}$ three-neck round-bottomed flask equipped with a magnetic stirrer, thermometer, DeanStark distilling trap, reflux condenser and nitrogen supply system, $78.75 \mathrm{~g}(0.8750 \mathrm{~mol})$ of 1,4-butanediol, $38.28 \mathrm{~g}(0.3750 \mathrm{~mol})$ of propylene carbonate and $0.09 \mathrm{~g}(0.25 \mathrm{mmol})$ of $\mathrm{Ti}(\mathrm{OBu})_{4}$ were placed. The reaction was carried out for $6 \mathrm{~h}$ at $165-170{ }^{\circ} \mathrm{C}$ under atmospheric pressure with continuously removal of 1,2propylene glycol by co-distillation with $n$-heptane, until no 1,2-propylene glycol was observed in the distillate. Then, the solvent was distilled off and $48.55 \mathrm{~g}$ $(0.2500 \mathrm{~mol})$ of dimethyl terephthalate was added. The reaction with a DMT was carried out for $5 \mathrm{~h}$ at $150{ }^{\circ} \mathrm{C}$ under inert gas flow until no distillation of methanol was observed. The final step - removal of an excess of propylene carbonate and the polycondensation was proceeded under reduced pressure $(0.2 \mathrm{mbar})$ at 150 $200{ }^{\circ} \mathrm{C}$ till required molar mass of oligo(tetramethylene terephthalate-co-carbonate) was attained. About $93.4 \mathrm{~g}$ of the product (TC4-39) with molar mass of $19500 \mathrm{~g} / \mathrm{mol}$ containing $39 \mathrm{~mol} \%$ of carbonate units was obtained.

TC4-39: ${ }^{1} \mathrm{H}$ NMR $\left(\mathrm{CDCl}_{3}, 400 \mathrm{MHz}\right): \delta(\mathrm{ppm})=8.08(\mathrm{~s}$, $4 \mathrm{H}), 4.43$ (t, 4H, $J=6.0 \mathrm{~Hz}$ ), 4.32 (t, $4 \mathrm{H}, J=6.0 \mathrm{~Hz}), 4.20$ (t, $4 \mathrm{H}, J=6.2 \mathrm{~Hz}), 4.15(\mathrm{t}, 4 \mathrm{H}, J=6.2 \mathrm{~Hz}), 3.72(\mathrm{t}, 4 \mathrm{H}, J=6.1 \mathrm{~Hz})$, $3.66(\mathrm{t}, 4 \mathrm{H}, J=6.1 \mathrm{~Hz}), 1.95(\mathrm{bs}, 4 \mathrm{H}), 1.89(\mathrm{bs}, 4 \mathrm{H}), 1.77-1.54$ (m, 8H).

FTIR (KBr): 3550, 2964, 2903, 1745, 1715, 1247, 1120, $929,728 \mathrm{~cm}^{-1}$.

Synthesis of poly(tetramethylene carbonate)

In a $1000 \mathrm{~cm}^{3}$ three-neck round-bottomed flask equipped with a magnetic stirrer, thermometer, distilling condenser and nitrogen supply system, $22.96 \mathrm{~g}$ $(0.2546 \mathrm{~mol})$ of 1,4-butanediol, $37.33 \mathrm{~g}(0.1697 \mathrm{~mol})$ of BMC4 and $0.09 \mathrm{~g}(0.2 \mathrm{mmol})$ of $\mathrm{Ti}(\mathrm{OBu})_{4}$ were placed. The reaction was carried out at $165-180{ }^{\circ} \mathrm{C}$ for $6 \mathrm{~h}$ under atmospheric pressure with a nitrogen flow, until no methanol was observed in the distillate (the refractive index was measured). Then, the reaction was continued under reduced pressure - $0.5 \mathrm{mbar}\left(160{ }^{\circ} \mathrm{C}\right.$, $1 \mathrm{~h}) .30 .6 \mathrm{~g}$ of the poly(tetramethylene carbonate) (CD4) was obtained as a white solid with $\mathrm{M}_{\mathrm{n}}=$ $11300 \mathrm{~g} / \mathrm{mol}$.

CD4: ${ }^{1} \mathrm{H}$ NMR $\left(\mathrm{CDCl}_{3}, 400 \mathrm{MHz}\right): \delta(\mathrm{ppm})=4.14(\mathrm{t}, 4 \mathrm{H}$, $J=6.2 \mathrm{~Hz}$ ), 3.67 (t, $4 \mathrm{H}, J=6.0 \mathrm{~Hz}), 3.42$ (t, $4 \mathrm{H}, J=6.1), 1.74$ (bs, 8H).

FTIR (KBr): 2964, 1742, 1247, 928, $772 \mathrm{~cm}^{-1}$.

\section{Results and discussion}

Synthesis of poly(alkylene terephthalate-co-carbonate)s

In this study poly(alkylene terephthalate-co-carbonate)s were obtained in the melt by polycondensation method. Dimethyl terephthalate (DMT) was applied as a source of terephthalate units and dimethyl carbonate (DMC) or propylene carbonate (PC) as a source of carbonate units.

Synthesis of poly(tetramethylene terephthalate-co-carbonate) using dimethyl carbonate (DMC) as a source of carbonate linkages

Due to low cost, environmentally friendly dimethyl carbonate (DMC) was used by us as a source of carbonate linkages in the synthesis of aliphatic-aromatic poly(ester-carbonate)s. First experiments were carried out directly with DMC when all monomers were added simultaneously. The main problem encountered in the synthesis of poly(ester-carbonate) from dimethyl carbonate was co-distillation of the starting material with the by-product (methanol) which distorts the molar ratio of the desired monomers. We tested several

Table 1 Influence of the reaction conditions on the amount of carbonate units introduced into poly(tetramethylene phthalate-co-carbonate) molecules

\begin{tabular}{|c|c|c|c|c|c|}
\hline Run & Method of carbonate linkages introduction & $\begin{array}{l}\text { Amount of } \\
\text { DMC used } \\
\text { mol. } \%\end{array}$ & $\begin{array}{l}\text { Reaction } \\
\text { time }^{\mathrm{b}} \\
\mathrm{h}\end{array}$ & $\begin{array}{l}\mathrm{M}_{\mathrm{n}}{ }^{\mathrm{c}} \\
\mathrm{g} / \mathrm{mol}\end{array}$ & $\begin{array}{l}\text { Amount of carbonate } \\
\text { units in the product } \\
\text { mol. } \%\end{array}$ \\
\hline 1 & DMC; distillation of methanol carried out continuously & 400 & 6 & 3100 & 5 \\
\hline 2 & DMC; generation of methanol under reflux before distillation ${ }^{\mathrm{d}}$ & 400 & 6 & 2850 & 9 \\
\hline 3 & DMC introduced in 3 portions ${ }^{\mathrm{e}}$ & 400 & 8 & 3500 & 10 \\
\hline
\end{tabular}

${ }^{\text {a }}$ Calculated as mol.\% of DMT

${ }^{\mathrm{b}}$ Reaction time of the second step after DMC was added

${ }^{\mathrm{c}}$ Calculated from ${ }^{1} \mathrm{H}$ NMR spectra

${ }^{\mathrm{d}}$ Procedure was repeated 3 times

${ }^{\mathrm{e}}$ Reaction was carried out according to a similar manner as in run 2. 
Fig. $1{ }^{1} \mathrm{H}$ NMR $(400 \mathrm{MHz}$, $\mathrm{CDCl}_{3}$ ) spectrum of the intermediate product (BMC4) obtained from DMC and 1,4-butanediol
$92 \%$<smiles>COC(=O)OCCCCOC(=O)O[PH3+]</smiles>

$8 \%$ approaches to limit this fault. Firstly, the process was divided into two steps. At the first step oligo(tetramethylene terephthalate) was obtained in the reaction of dimethyl terephthalate and 1,4-butanediol. After removing almost whole theoretical amount of methanol, DMC was added and the polycondensation was continued under reflux without removing methanol from the reaction mixture for $2 \mathrm{~h}$. Then, methanol/DMC was gradually distilled off.
Scheme 1 Synthesis of poly(alkylene terephthalate-cocarbonate) from DMT, alkylene bis(methylcarbonate) and $\alpha, \omega$-diol<smiles>COC(=O)c1ccc(C(=O)OC)cc1</smiles><smiles>CC(C)(O)CC(C)(C)OC(=O)OC(C)(C)NC(C)(C)CC(C)(C)OC(=O)c1ccc(C(=O)OC(C)(C)CC(C)(C)O)cc1</smiles>

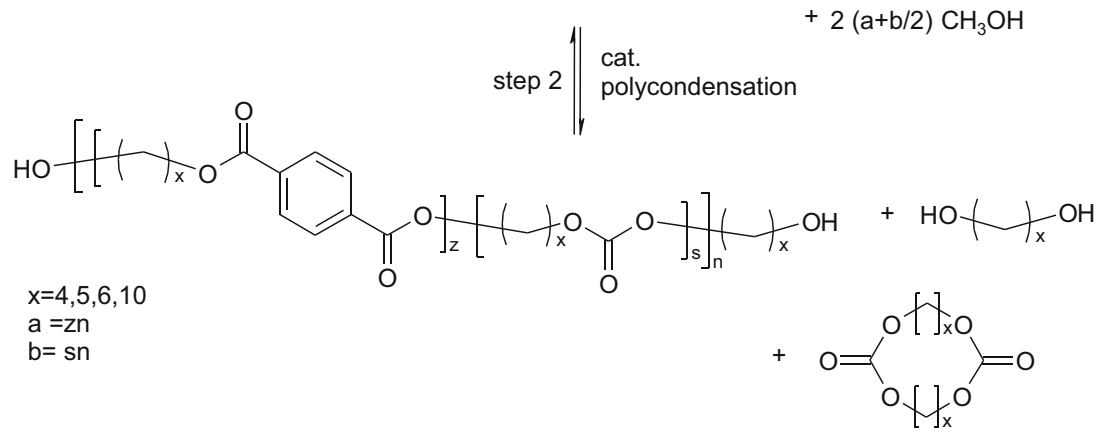


Scheme 2 Side reactions caused by water during synthesis of poly(ester-carbonate) $\mathrm{s}$
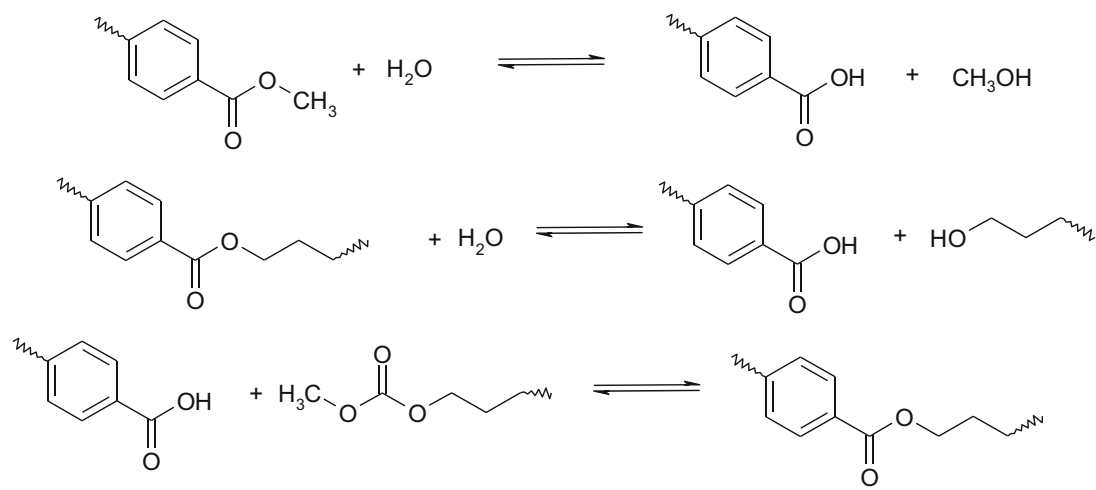

$+\mathrm{CH}_{3} \mathrm{OH}+\mathrm{CO}_{2}$
When the content of methanol in the distillate was lower than $3 \%$ (refractive index) the reaction again was carried out under reflux for $2 \mathrm{~h}$ to generate the next portion of methanol. This procedure was repeated 3 times. The highest amount of carbonate units in the product did not exceeded $10 \mathrm{~mol} . \%$ after $8 \mathrm{~h}$ of polycondensation (Table 1, run 3 ).
Synthesis of poly(tetramethylene terephthalate-co-carbonate) using tetramethylene bis(methyl carbonate) (BMC4) as a source of carbonate linkages [34]

In order to avoid uncontrolled distillation of dimethyl carbonate with methanol a new intermediate-alkylene

Table 2 Molecular characteristics of poly(alkylene terephthalate-co-carbonate)s

\begin{tabular}{|c|c|c|c|c|c|c|c|c|}
\hline Run & Sample & $\begin{array}{l}\mathrm{M}_{\mathrm{n}}{ }^{\mathrm{a}} \\
\mathrm{g} / \mathrm{mol}\end{array}$ & $\begin{array}{l}\mathrm{M}_{\mathrm{n}}{ }^{\mathrm{b}} \\
\mathrm{g} / \mathrm{mol}\end{array}$ & $\begin{array}{l}\mathrm{M}_{\mathrm{w}}{ }^{\mathrm{b}} \\
\mathrm{g} / \mathrm{mol}\end{array}$ & $\mathrm{DI}^{\mathrm{b}}$ & $\mathrm{R}^{\mathrm{a}} \mathrm{c}$ & $\mathrm{L}_{\mathrm{nT}}{ }^{\mathrm{a} d}$ & $\mathrm{~L}_{\mathrm{nC}}{ }^{\text {a e }}$ \\
\hline 1 & CD4 & 3250 & 4040 & 11300 & 2.8 & - & - & - \\
\hline 2 & TC4-9 & 2850 & 3250 & 9425 & 2.9 & - & - & - \\
\hline 3 & TC4-77 & 5050 & 10700 & 27400 & 2.6 & 1.10 & 2.48 & 1.65 \\
\hline 4 & TC4-57 & 6200 & 7100 & 18600 & 2.6 & 0.99 & 2.13 & 1.99 \\
\hline 5 & TC4-51 & 3050 & 3470 & 8330 & 2.4 & 1.01 & 2.06 & 1.99 \\
\hline 6 & TC4-50 & 8260 & 18760 & 32790 & 1.7 & 1.02 & 2.17 & 1.81 \\
\hline 7 & TC4-46 & 13800 & 24790 & 39815 & 1.6 & 1.01 & 2.30 & 1.73 \\
\hline 8 & TC4-45 & 10750 & 10410 & 30450 & 2.9 & 1.01 & 2.17 & 1.81 \\
\hline 9 & TC4-43 & 15200 & 12300 & 32000 & 2.6 & 1.01 & 2.11 & 1.82 \\
\hline 10 & TC4-39 ${ }^{f}$ & 4950 & 6580 & 18100 & 2.7 & 1.01 & 1.70 & 2.29 \\
\hline 11 & TC4-27 ${ }^{\mathrm{g}}$ & 9600 & - & - & - & 1.01 & 3.59 & 1.36 \\
\hline 12 & TC4/5-67 ${ }^{\mathrm{h}}$ & 12630 & 24150 & 50460 & 2.1 & - & - & - \\
\hline 13 & TC5-49 & 12740 & 13280 & 32240 & 2.4 & - & - & - \\
\hline 14 & TC6-47 & 8205 & 8600 & 24230 & 2.8 & - & - & - \\
\hline 15 & TC6 $/ 4^{-49}{ }^{i}$ & 18460 & 18400 & 41220 & 2.7 & - & - & - \\
\hline 16 & $\mathbf{T C 1 0} / \mathbf{4}^{-50}{ }^{\mathrm{j}}$ & 14650 & 17315 & 51315 & 2.9 & - & - & - \\
\hline
\end{tabular}

${ }^{\text {a }}$ Calculated from ${ }^{1} \mathrm{H}$ NMR spectra

${ }^{\mathrm{b}}$ Measured by GPC (universal calibration)

${ }^{\mathrm{c}} \mathrm{R}$-randomness degree

${ }^{\mathrm{d}} L_{\mathrm{nT}}$-number average terephthalate sequence length

${ }^{\mathrm{e}} L_{\mathrm{nC}}$-number average carbonate sequence length

${ }^{\mathrm{f}}$ TC4-39 was obtained with the usage of propylene carbonate

${ }^{\mathrm{g}}$ Reaction carried out at $\mathrm{T}>240{ }^{\circ} \mathrm{C}$. Decarboxylation was observed

${ }^{\mathrm{h}}$ Molar ratios: BMC4:BMC5=1:1 and 1,4-BDO:1,5-PDO=1:1

${ }^{\mathrm{i}}$ Molar ratios: 1,6-HDO:(DMT+BMC6) $=1: 1$ and 1,4-BDO:(DMT+BMC6 $)=0.5: 1$

${ }^{\mathrm{j}}$ Molar ratios: 1,10-DDO:(DMT+BMC10 $)=1: 1$ and 1,4-BDO: $($ DMT + BMC10 $)=0.5: 1$ 
Fig. $2{ }^{1} \mathrm{H}$ NMR $(400 \mathrm{MHz}$, $\mathrm{CDCl}_{3}$ ) spectrum of cyclobis(tetramethylene carbonate) formed as a byproduct

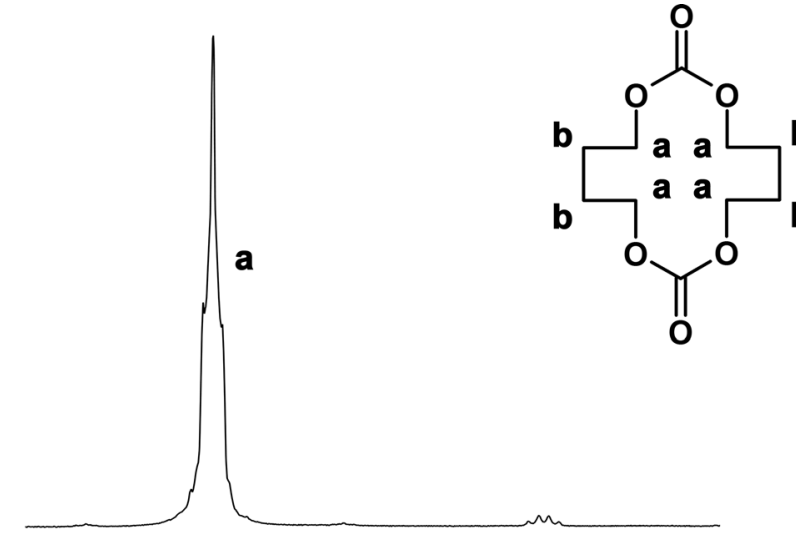

\begin{tabular}{llllllllllll}
\hline 4.4 & 4.3 & 4.2 & 4.1 & 4.0 & 3.9 & 3.8 & 3.7 & 3.6 & 3.5
\end{tabular}

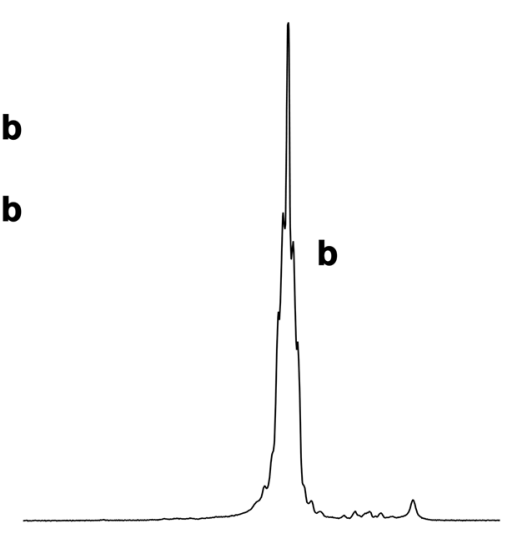

$\begin{array}{llllllll}2.1 & 2.0 & 1.9 & 1.8 & 1.7 & 1.6 & 1.5\end{array}$ ppm

bis(methylcarbonate) (BMC) monomer is hereby proposed [10]. Additionally, in case of using $\mathrm{BMC}$ the reaction can be carried out at higher temperature (up to $230{ }^{\circ} \mathrm{C}$ ), so the polycondensation proceeds with higher rate. This solid monomer was obtained in the reaction of 1,4-butanediol (1,4-BD) with molar excess of DMC (1:6) in the presence of $\mathrm{Ti}(\mathrm{OBu})_{4}$ as a catalyst [10]. It should be mentioned that despite of high molar excess of DMC, some amount of a tricarbonate was present in the product (Fig. 1).

The amount of the tricarbonate was calculated from the ${ }^{1} \mathrm{H}$ NMR spectrum of the product taking into account the intensity of signals corresponding to $\mathrm{CH}_{3}$ protons $(3.77 \mathrm{ppm})$ and $\mathrm{CH}_{2} \mathrm{O}$ protons (4.16 ppm) adjacent to carbonate linkages, respectively (Fig. 1) [10].

$[$ dimer $]$, mol $\%=\frac{6 b-4 a}{24} \cdot 100 \%$

where $a$ - area of signals corresponding to methyl protons $=6$ and $b$-area of signals corresponding to methylene protons.

The synthesis of poly(ester-carbonate)s from BMC, DMT and 1,4-butanediol was carried out in two steps (experimental section). At the first step methanol was distilled off, resulting in the formation of oligomers terminated with 4-hydroxybutyl groups (Scheme 1, step 1). The molar ratio of diol to the sum of $\mathrm{BMC}$ and DMC should be greater than 2 usually 2.1-2.2.

It was observed that the presence of water traces in starting monomers leads to the loss of carbonate groups in the resultant copolymer. Similar effect was observed when terephthalic acid was used in the reaction with BMC4 and 1,4-butanediol instead of DMT. Water can hydrolyze carbonate linkages or carboxylic acid, formed in situ, can react with carbonate groups leading to decarboxylation (Scheme 2).

Thus, all starting materials should be dried thoroughly prior to the synthesis. After removing more than 95-97 \% of theoretical amount of methanol the temperature was raised up to 200-220 ${ }^{\circ} \mathrm{C}$ and the reaction was continued under reduced pressure (Scheme 1, step 2). Under such conditions residues of methanol together with small amount of 1,4-butanediol was distilled off and molar mass of carbonate oligomer increased up to $15300 \mathrm{~g} / \mathrm{mol}$ (Table 2). It was observed that in the case of the polycondensation carried out at $220{ }^{\circ} \mathrm{C}$ small amount of white crystals was formed in a distillation cooler. The spectral analysis and melting point measurement of these crystals (m.p. $173-174{ }^{\circ} \mathrm{C}$ ) $[35,36]$ revealed that during polycondensation, besides 1,4-butanediol, 14-membered cyclobis(tetramethylene carbonate) was formed as a by-product (Fig. 2).
Scheme 3 Formation of cyclobis(tetramethylene carbonate) as a by-product in the synthesis of poly(tetramethylene terephthalate-co-carbonate)

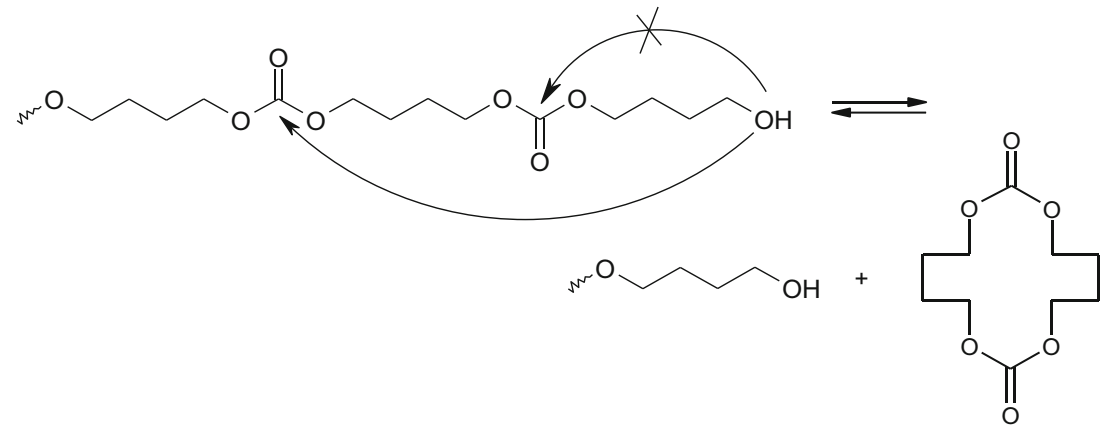


Scheme 4 Reaction of terminal carbonate vs ester groups with alcohol
1)<smiles>C=COCCCCOC(=O)OCCCCOC(=O)OCCCCOC(=O)OCCCCOC</smiles>

2)

carbonate alcoholysis

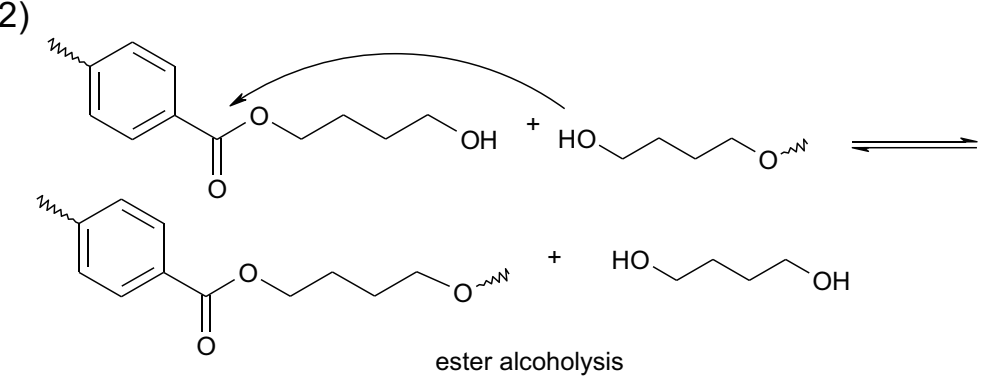

The reaction proceeds according to 'back-biting' manner (Scheme 3). It is characteristic that no sevenmembered cyclic carbonate is formed, but much less volatile cyclobis(tetramethylene carbonate). It should be added that due to the presence of ester units in the formed copolymer, the probability that terminal dicarbonate units are present in poly(ester-carbonate) chains is lower than in the case of synthesis of poly(tetramethylene carbonate) alone and the yield of cyclobis(tetramethylene carbonate) was relatively low (1-2\%).
It is worth mentioning that in the case of using trimethylene bis(methylcarbonate) only small amount of trimethylene carbonate units can be introduced into resultant polymer due to back-biting reaction leading to volatile trimethylene carbonate.

It was found that the reaction temperature should not be higher than $220-225^{\circ} \mathrm{C}$. Above this temperature decarboxylation takes place leading to drastically reduced concentration of tetramethylene carbonate units in the resultant polymer (Table 2, run 10). It should be added that in contrast to the
Fig. $3{ }^{1} \mathrm{H}$ NMR $(400 \mathrm{MHz}$, $\mathrm{CDCl}_{3}$ ) spectra of poly(alkylene terephthalate-co-carbonate)s based on different $\alpha, \omega$-diols: 1,4-butanediol (TC4-46) (a), 1,5-pentanediol (TC5-49) (b), 1,6-heksanediol (TC6-47) (c) and 1,10-decanediol (TC10/4-50) (d)

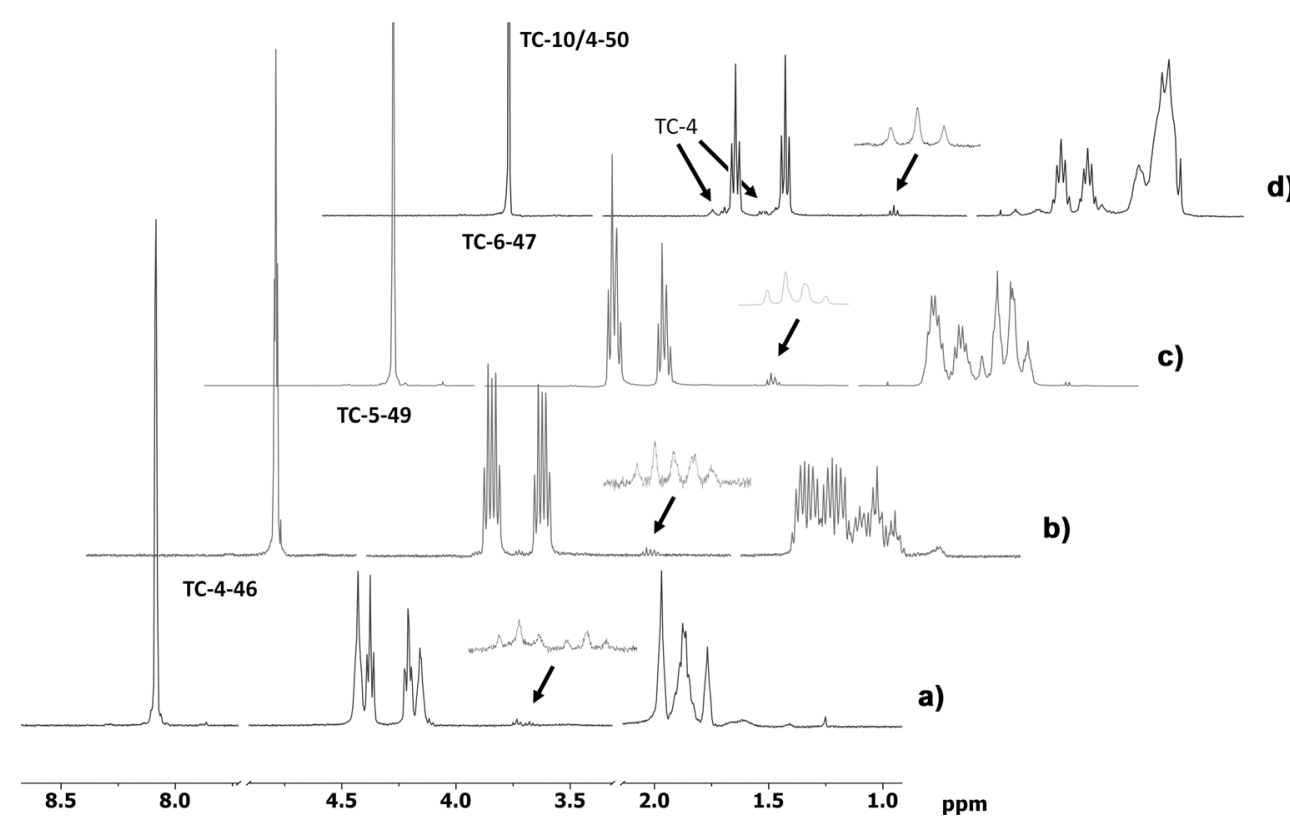


Fig. $4{ }^{13} \mathrm{C}$ NMR (400 MHz, $\mathrm{CDCl}_{3}$ ) spectrum of poly(tetramethylene terephthalate-co-carbonate) (TC4-46)

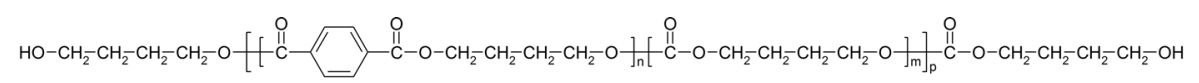

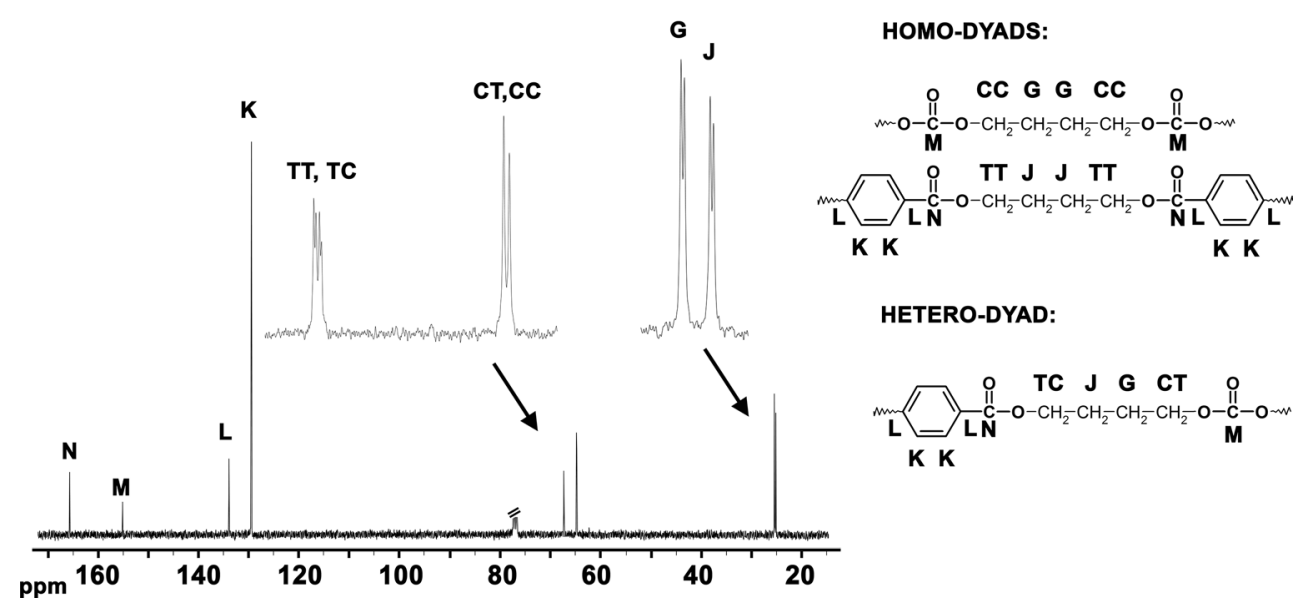

synthesis of polyester, synthesis of poly(ester-carbonate) proceeds with lower rate. The attack of hydroxyl groups at carbonyl group in terminal carbonate linkages can lead to volatile 1,4-butanediol and oligomer (1a) or two oligomers (1b), whereas in case of the reaction with terminal ester group only volatile product and oligomer are formed (2) (Scheme 4).
Thus, the reaction (1b) is unproductive and does not lead to the increase in the polymer molar mass.

It was not possible to obtain high molar mass poly(tetramethylene terephthalate)s containing more than $60 \%$ of terephthalate when planned molar ratio BMC to DMT was used. In this case due to high melting point of the
Fig. 5 MALDI-TOF mass spectrum of poly(tetramethylene terephthalate-co-carbonate)

(TC4-77)
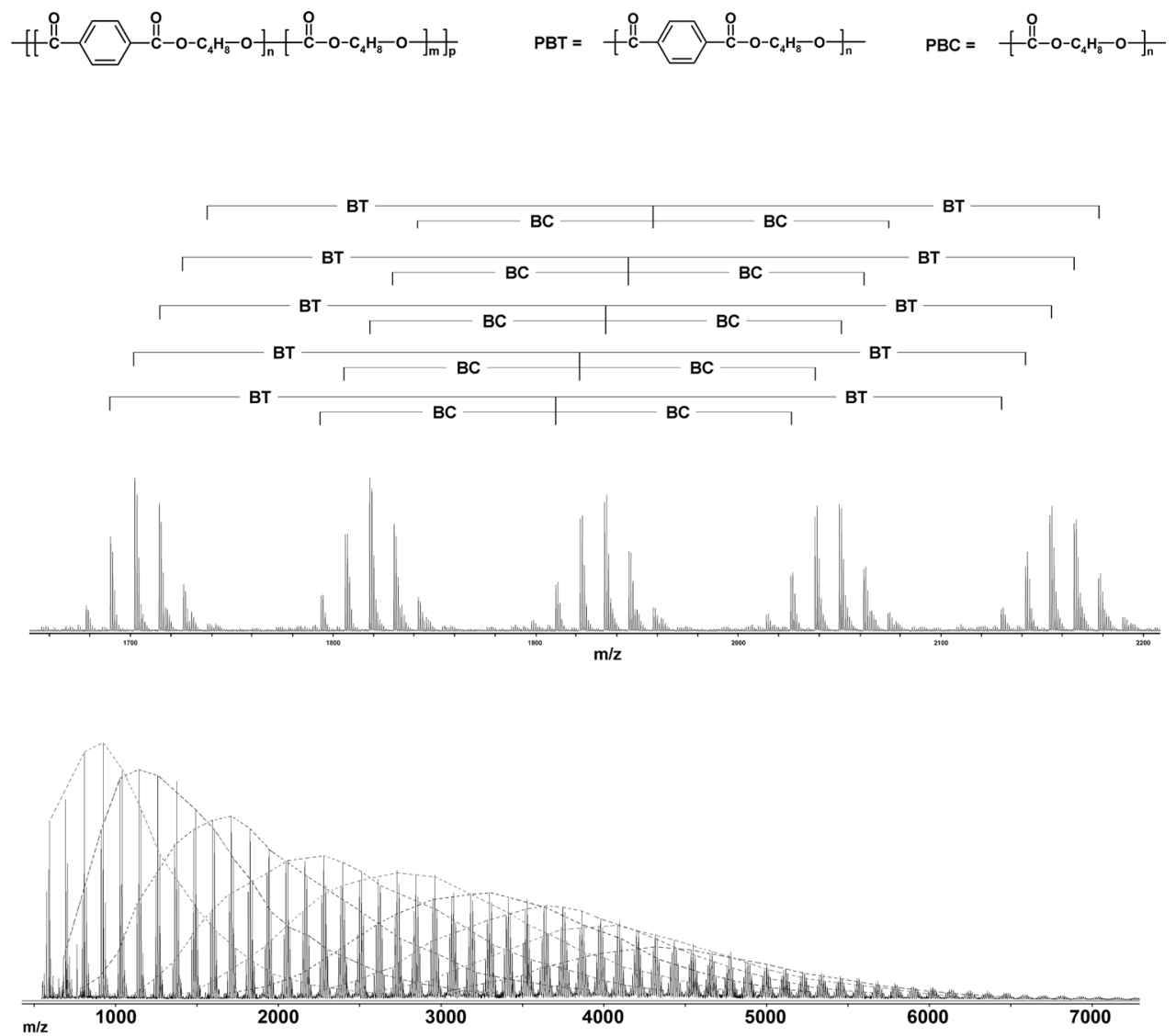
Fig. 6 Polymerix software; The amount of macromolecules of exact combination of terephthalate and carbonate units in poly(tetramethylene terephthalate-co-carbonate) (TC4-77)

\section{BC units}

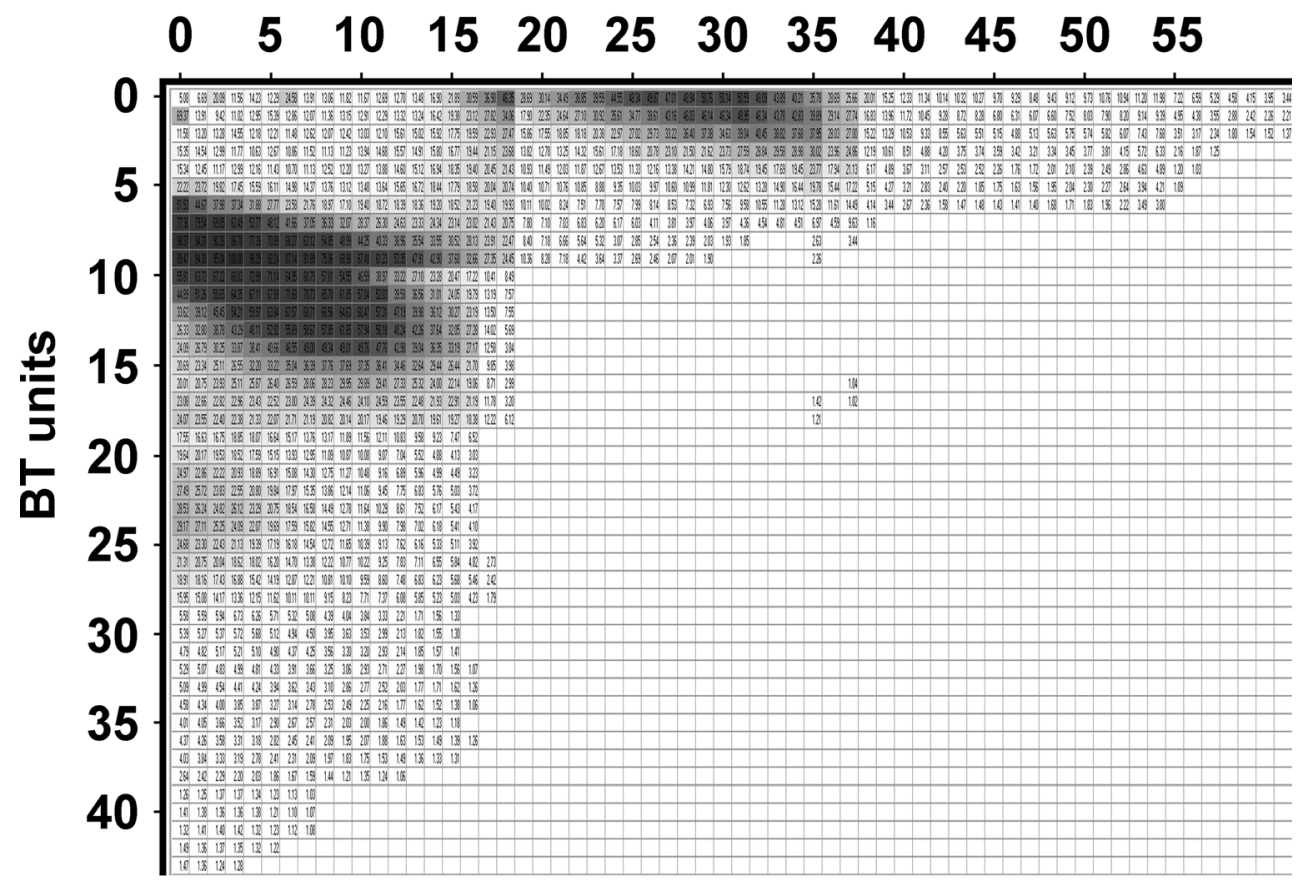

copolymer the stirring of the reaction mixture at temperature lower than $225^{\circ} \mathrm{C}$ was difficult. Copolymers with higher than $60 \%$ of terephthalate units contribution were obtained when excess of tetramethylene bis(methylcarbonate) was used and the process was proceeded at $240{ }^{\circ} \mathrm{C}$ at which temperature partial decarboxylation took place.

We have observed that the presence of carbonate units prevents the yellowing of the polymer during the polycondensation at high temperature. In contrast, aliphatic-aromatic copolyesters like poly(tetramethylene terephthalate-co-adipate) obtained under similar reaction conditions were colored.

Poly(pentamethylene terephthalate-co-carbonate) based on 1,5-pentanediol was obtained according to a similar manner (Table 2, run 13).

In case of longer diols such as 1,6-hexanediol and 1,10-decanediol it was impossible to obtain copolymers of high molar mass because of high boiling points of diols (250 and $297{ }^{\circ} \mathrm{C}$, respectively) (Table 2, run 14). To solve this problem we have performed the experiments in which the molar excess of 1,6-hexanediol or 1,10decanediol was replaced by that of 1,4-butanediol, which distills more easily under used reaction conditions (Table 2, runs
15-16 and Fig. 3). The small intensity signals which can be assigned to protons $\mathrm{C}(\mathrm{O}) \mathrm{OCH}_{2} \mathrm{CH}_{2} \mathrm{CH}_{2} \mathrm{CH}_{2} \mathrm{OC}(\mathrm{O})$ which are present in the ${ }^{1} \mathrm{H}$ NMR spectrum of poly(decamethylene terephthalate-co-carbonate) (Fig. 3d) correspond to small amount of tetramethylene units (TC-4) which are incorporated in the structure of the polymers $\mathbf{T C 1 0} /{ }_{\mathbf{4}} \mathbf{- 5 0}$.

Structure of the obtained poly(alkylene terephthalate-cocarbonate)s was also confirmed by ${ }^{13} \mathrm{C}$ NMR spectra analysis (exemplary spectra is shown for TC4-46 in Fig. 4). In the range of 64-67 ppm there are signals which can be assigned to carbon atoms of $\mathrm{CH}_{2} \mathrm{O}$ groups characteristic for heterodiads and homodiads. There are two signals from carbonyl ester and carbonate carbon atoms (166 and $155 \mathrm{ppm})$. The ${ }^{13} \mathrm{C}$ NMR spectrum additionally confirmed random structure of the poly(tetramethylene terephthalate-co-carbonate).

The chemical structure of the obtained poly(alkylene terephthalate- $c o$-carbonate)s was confirmed by MALDI-TOF mass spectrum (Figs. 5 and 6). In the spectrum the series differ in the number of terephthalate units $(220.23 \mathrm{Da})$. The peaks of these series are characterized by mass increment $130.14 \mathrm{Da}$ from one peak to the next, and is equal to mass of the tetramethylene carbonate unit.

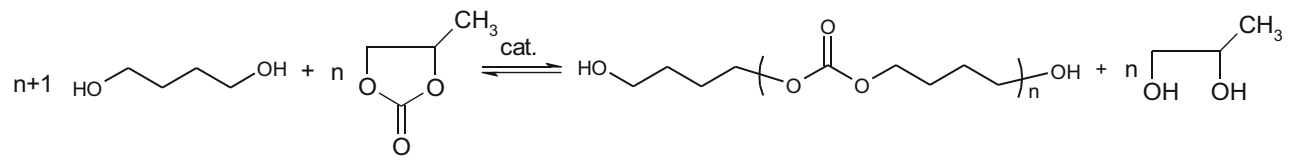

Scheme 5 Synthesis of oligo(tetramethylene carbonate) from propylene carbonate and 1,4-butanediol 


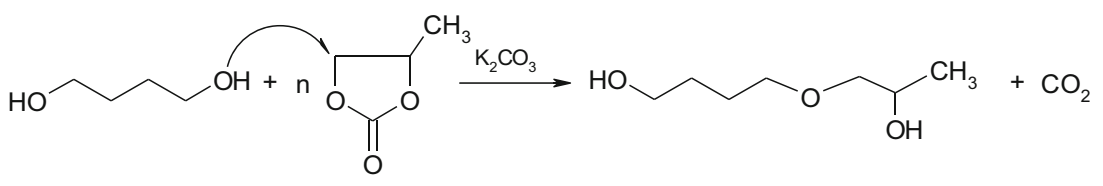

Scheme 6 Formation of ether linkages in the reaction of diol with propylene carbonate in the presence of basic catalyst

The amount of macromolecules of exact combination of terephthalate and carbonate units is visualized in Fig. 6. The dark areas show the combinations of the greatest intensity. It is seen that copolymer contains mainly macromolecules with 0 to 12 carbonate and 5 to 14 terephthalate units per molecule. The second area of macromolecules of high intensity is observed for macromolecules containing 0-3 terephthalate and 20-35 carbonate units. It should be underlined that it is rather difficult for interpretation results obtained by MALDI-TOF mass spectrometry. The results refer only to the fractions of the polymer which were ionized during the MALDI-TOF experiments. The ionization ability depends on polymer chemical structure.

Synthesis of poly (tetramethylene terephthalate-co-carbonate) using propylene carbonate (PC) as a source of carbonate linkages

Propylene carbonate (PC) is cheap and non-toxic monomer which can be used as a carbonate linkages precursor. It is easily obtained from propylene oxide and $\mathrm{CO}_{2}$. The synthesis of poly(ester-carbonates) was carried out in two steps. Firstly, PC was reacted with 1,4-butanediol (Scheme 5). The amount of 1,4-butanediol used in the first step was calculated for molar ratio of 1,4-BD to the sum of DMT and PC equals 1.5:1.
The reaction was carried out in an azeotropic solvent (n-heptane) [9, 37], so the by-product (1,2-propylene glycol) was removed from the reaction mixture as an hetero-azeotrope. The attempts of removing of 1,2-propylene glycol by distillation failed due to its co-distillation together with 1,4-butanediol.

As far as catalyst is concerned, it was found that the same catalyst $\left(\mathrm{Ti}(\mathrm{OBu})_{4}\right)$ used in the first step can be applied in the polycondensation step. It should be mentioned that the use of basic catalyst such as $\mathrm{K}_{2} \mathrm{CO}_{3}$, which is suitable in the synthesis of alkylene bis(methylcarbonate), cannot be applied in the reaction of diol with propylene carbonate. Basic catalysts promote the formation of ether linkages in a high extent (Scheme 6) [9].

The reaction progress was monitored by IR spectroscopy. When in the spectrum of the reaction mixture an absorption band at $1795 \mathrm{~cm}^{-1}$ (characteristic for carbonyl group of five-membered cyclic carbonate) disappeared, the solvent was distillated off and DMT was added. Next steps were very similar to the process in which tetramethylene bis(methylcarbonate) was used.

In contrast to the method in which dimethyl carbonate was used, the synthesis with propylene carbonate can be carried out in one pot, and there is no need to separate semi-product to obtain poly(ester-carbonate) with intended carbonate units participation.
Fig. $7{ }^{1} \mathrm{H}$ NMR $(400 \mathrm{MHz}$, $\mathrm{CDCl}_{3}$ ) spectrum of the poly(tetramethylene terephthalate-co-carbonate) (TC4-46)

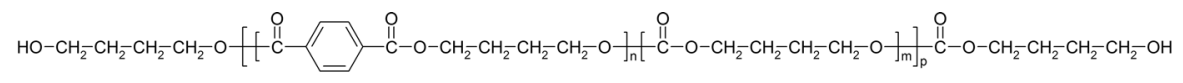

END-GROUPS:
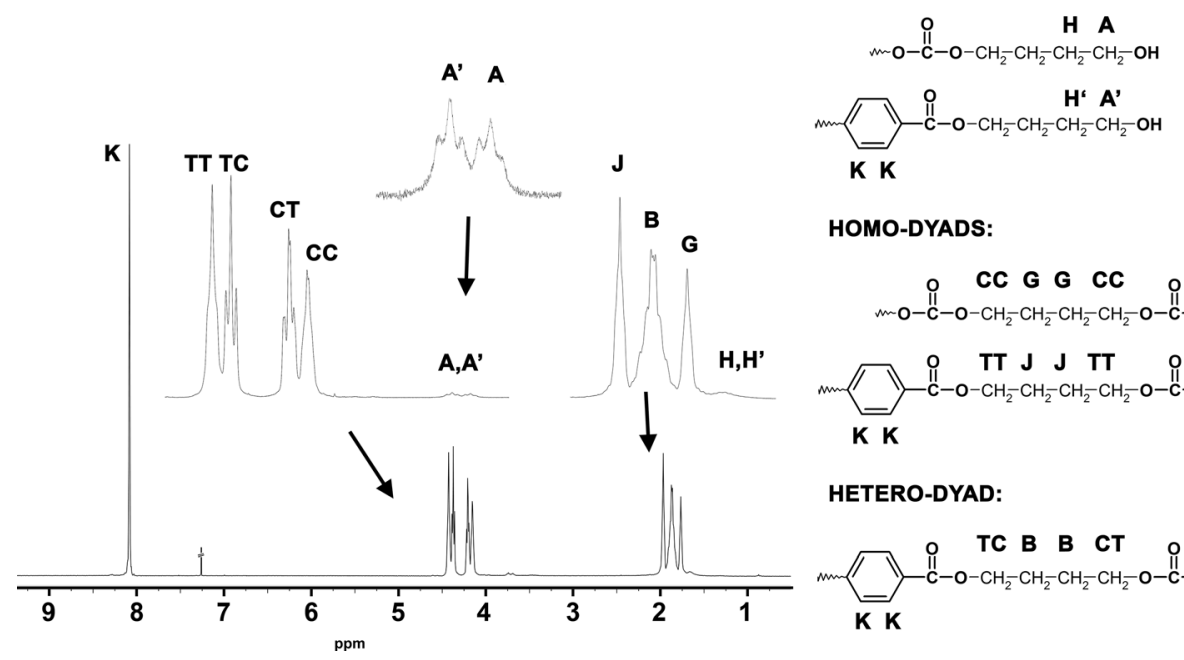

HOMO-DYADS:
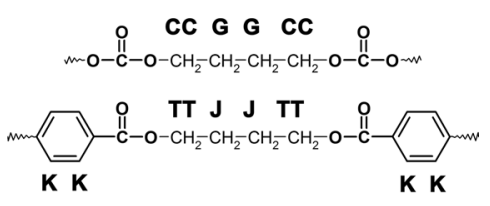

HETERO-DYAD:

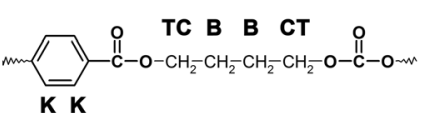




\section{Molecular characterization}

The ${ }^{1} \mathrm{H}$ NMR spectrum of poly(tetramethylene terephthalateco-carbonate) (TC4-46), together with the corresponding chemical shift assignments, is presented in Fig. 7.

Poly(ester-carbonate)s' composition was calculated using the relative areas of the signals of the $\mathrm{OCH}_{2}$ protons of the terephthalate units located at 4.35$4.45 \mathrm{ppm}(\mathrm{TT}+\mathrm{TC})$ and the $\mathrm{OCH}_{2}$ protons of the carbonate units at $4.13-4.23 \mathrm{ppm}(\mathrm{CC}+\mathrm{CT})$. To estimate microheterogeneity the degree of randomness $(R)$ was calculated. This was accomplished by taking into account the intensity of resonance peaks of the $\mathrm{OCH}_{2}$ protons. The degree of randomness (R) according to Yamadera and Murano is defined [38] as:

$$
\begin{gathered}
R=P_{T C}+P_{C T} \\
P_{T C}=\frac{f_{T C}}{f_{T C}+f_{T T}}=1 / L_{n C} \\
P_{C T}=\frac{f_{C T}}{f_{T C}+f_{C C}}=1 / L_{n T}
\end{gathered}
$$

where $P_{T C}$ and $P_{C T}$ are the probability of finding a T unit next to a $\mathrm{C}$ unit and the probability of finding a $\mathrm{C}$ unit next to a $\mathrm{T}$ unit, respectively, while $f_{T T}, f_{T C}, f_{C T}$, and $f_{C C}$ represent the triads fraction, calculated from the integral intensities of the resonance signals TT, TC, CT, and CC, respectively. $L_{\mathrm{nC}}$ and $L_{\mathrm{nT}}$ stand for the number-average sequence length, the socalled block length, of the $\mathrm{C}$ and $\mathrm{T}$ units, respectively. In the case of random copolymers $R$ takes a value equal to 1, while for alternate copolymers equal to 2 and for block copolymers close to zero. For all polymers, as seen in Table 2, the degree

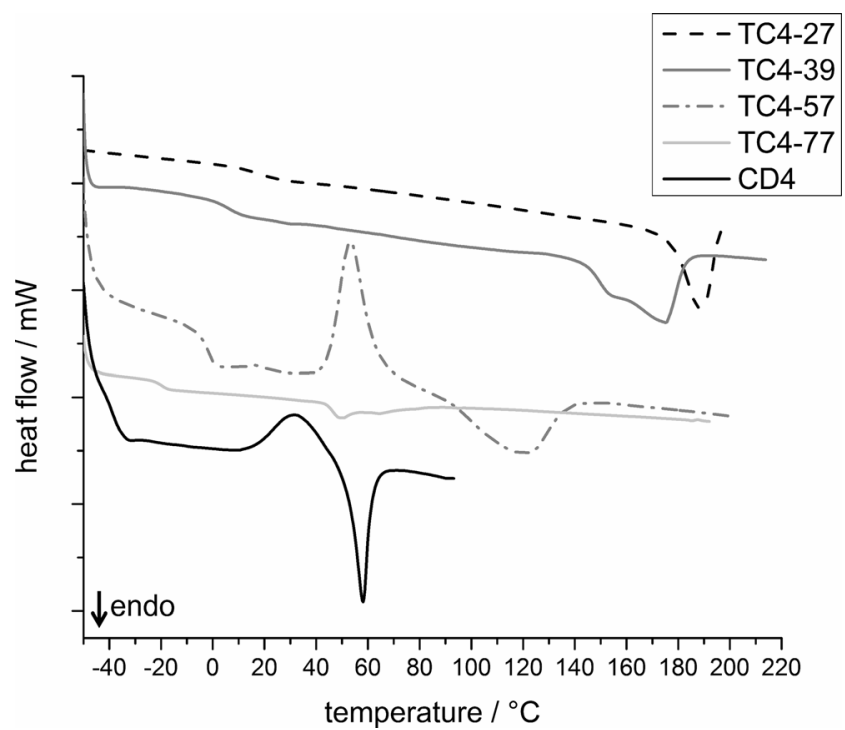

Fig. 8 DSC curves of poly(tetramethylene phthalate-co-carbonate)s of different amount of tetramethylene carbonate units. $\left(2^{\text {nd }}\right.$ heating of TC427, TC4-39, TC4-57 and CD4; $1^{\text {st }}$ heating of TC4-77)

of randomness was very close to 1 , indicating the random nature of the prepared poly(ester-carbonate)s. Similar results were obtained for copolymers based on both dimethyl carbonate and propylene carbonate as carbonate linkage sources. According to Yamadera and Murano, the number-average sequence length for terephthalate $\left(L_{\mathrm{nT}}\right)$ and carbonate $\left(L_{\mathrm{nS}}\right)$ units, also known as the corresponding block length, can be calculated using the same equations. The observation of signals corresponding to terminal groups $\mathrm{HOCH}_{2}$ also indicated that molar ratio of 4-hydroxybutyl carbonate to 4-hydroxybutyl terephthalate end groups is similar to that of terephthalate to carbonate units in the whole polymer.

\begin{tabular}{|c|c|c|c|c|c|c|c|c|c|}
\hline Run & Sample & $\begin{array}{l}\mathrm{M}_{\mathrm{w}} \\
\mathrm{g} / \mathrm{mol}\end{array}$ & $\begin{array}{l}\mathrm{T}_{\mathrm{g}} \\
{ }^{\circ} \mathrm{C}\end{array}$ & $\begin{array}{l}\mathrm{T}_{\mathrm{m} 1} \\
{ }^{\circ} \mathrm{C}\end{array}$ & $\begin{array}{l}\Delta \mathrm{H}_{\mathrm{m} 1} \\
\mathrm{~J} / \mathrm{g}\end{array}$ & $\begin{array}{l}\mathrm{T}_{\mathrm{m} 2} \\
{ }^{\circ} \mathrm{C}\end{array}$ & $\begin{array}{l}\Delta \mathrm{H}_{\mathrm{m} 2} \\
\mathrm{~J} / \mathrm{g}\end{array}$ & $\begin{array}{l}\mathrm{T}_{\mathrm{c}} \\
{ }^{\circ} \mathrm{C}\end{array}$ & $\begin{array}{l}\Delta \mathrm{H}_{\mathrm{c}} \\
\mathrm{J} / \mathrm{g}\end{array}$ \\
\hline 1 & CD4 & 11300 & -39 & 58.7 & 135.3 & - & - & 32.6 & 10.3 \\
\hline 2 & TC4-77 & 27400 & -13.6 & $50.02^{\mathrm{a}}$ & $18.0^{\mathrm{a}}$ & - & - & $\mathrm{b}$ & $\mathrm{b}$ \\
\hline 3 & TC4-57 & 18600 & -2.0 & $49.4^{\mathrm{a}}$ & $1.86^{\mathrm{a}}$ & 124.1 & 9.1 & $53.2^{\mathrm{c}}$ & $29.1^{\mathrm{c}}$ \\
\hline 4 & TC4-51 & 8330 & -3.0 & $44.1^{\mathrm{a}}$ & $0.58^{\mathrm{a}}$ & $150.4^{\mathrm{a}}$ & $36.8^{\mathrm{a}}$ & 114.0 & 34.9 \\
\hline 5 & TC4-39 & 18100 & 4.4 & $41.2^{\mathrm{a}}$ & $1.82^{\mathrm{a}}$ & 175.7 & 51.4 & 112.4 & 59.4 \\
\hline 6 & TC4-27 & - & 17.5 & - & - & 188.6 & 27.0 & 157.7 & 36.5 \\
\hline 7 & TC4-43 & 32000 & 2.9 & $44.4^{\mathrm{a}}$ & $2.62^{\mathrm{a}}$ & 144.4 & 43.8 & $61.2^{\mathrm{c}}$ & $39.0^{\mathrm{c}}$ \\
\hline 8 & TC4-46 & 39815 & 14.3 & - & - & 152.0 & 20.7 & 92.8 & 34.3 \\
\hline 9 & TC4-50 & 32790 & 18.9 & - & - & 149.2 & 41.0 & 85.8 & 57.5 \\
\hline
\end{tabular}

Table 3 Thermal properties of poly(tetramethylene terephthalate-co-carbonate)s containing different amount of carbonate units in the polymer chain. DSC measurement results

${ }^{\mathrm{a}} \mathrm{T}_{\mathrm{m}}$ observed only in a first cycle of measurement

${ }^{\mathrm{b}}$ No crystallization process was observed during the measurement conditions

${ }^{\mathrm{c}}$ Crystallization observed while second heating was proceeded 


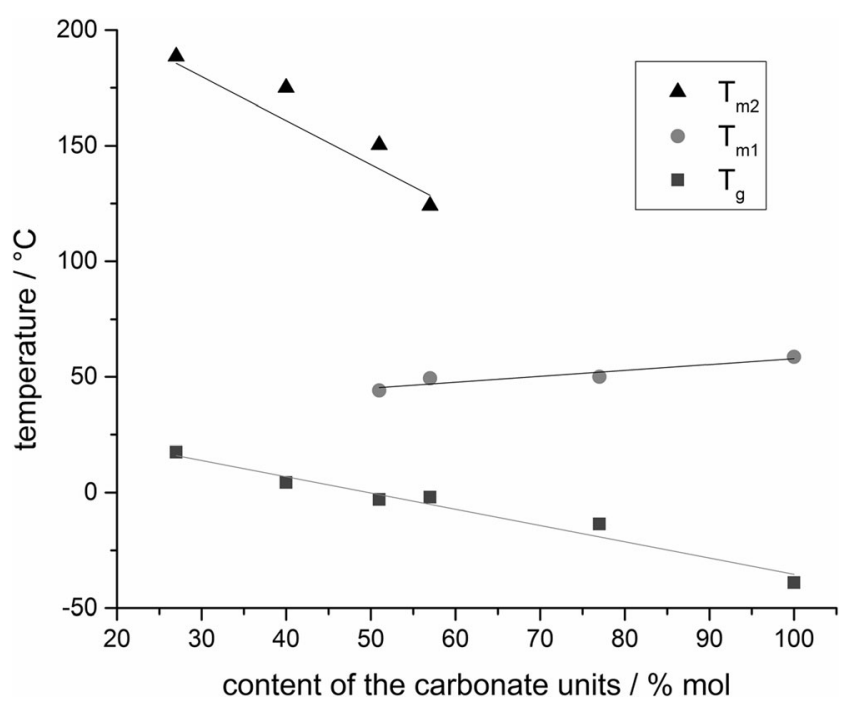

Fig. 9 Influence of the carbonate units content on transition temperatures of poly(tetramethylene terephthalate-co-carbonate)

In Table 2 calculated values for the degree of randomness and the number average block length for terephthalate and carbonate are collected. It is seen that for $50 / 50$ molar ratio, the block length is ca. 1 , what indicates that polymer has a random structure (Fig. 7, Table 2). The length of terephthalate block has decisive influence on copolymer biodegradation. When the number average block length is 3 or higher degradation rate is small and it is difficult to achieve complete biodegradation of aliphatic-aromatic polyester [29].

For poly(ester-carbonate)s obtained from other diols it was difficult to estimate the copolymer randomness by ${ }^{1} \mathrm{H}$ NMR method, due to overlapping of the signals corresponding to $\mathrm{OCH}_{2}$ protons (CC with $\mathrm{CT}$ and TT with TC) in the region 4.0-4.5 ppm (Fig. 3).

The highest molar mass $\left(\mathrm{M}_{\mathrm{w}}=\mathrm{ca} .50000 \mathrm{~g} / \mathrm{mol}\right)$ was obtained when the mixture of 1,4-butanediol and 1,5-butanediol as well as BMC4 and BMC5 were used in the reaction with DMT (Table 2, run 12).
Thermal analysis of poly(alkylene terephthalateco-carbonate)s

Thermal analysis of the poly(ester-carbonate)s was carried out using DSC. The first heating scan of the samples showed that the poly(ester-carbonate)s and polycarbonate are semicrystalline. The melting points and heat of fusion decreased with increasing tetramethylene carbonate (BC) unit content. The respective values are summarized in Table 3 .

The glass transition temperature decrease with the increasing of carbonate units content in the polymer chain, from $17.5^{\circ} \mathrm{C}$ for TC4-27 to $39^{\circ} \mathrm{C}$ for CD4 (100\% carbonate units).

In the DSC thermodiagrams two melting points can be observed (Fig. 8). The melting point of first type of crystallites is decreasing with the increase of the distortion of the polymer chains regular structure-in case of CD4, where is no aromatic units in the structure, the melting point is the highest $\left(59^{\circ} \mathrm{C}\right)$ (Table 3, run 1) and decrease down to $41.2{ }^{\circ} \mathrm{C}$ for TC4-39 (Table 3 run 5). The melting enthalpy $\left(\Delta \mathrm{H}_{\mathrm{m} 1}\right)$ of first type of crystallites increases with the increasing content of aliphatic carbonate units. The second type of the crystallites origins from aromatic ester units and melting point increases with the increasing number of terephthalic units - from $124{ }^{\circ} \mathrm{C}$ (TC4-57) to $188^{\circ} \mathrm{C}$ for TC4-27. Figure 9 shows the influence of the aliphatic carbonate units content on the thermal characteristics of the obtained products.

In case of samples with approximately $50 \mathrm{~mol} . \%$ of carbonate units content and relatively high molar mass (Table 3 run 8-9) one broad melting area in range of higher temperatures is observed what indicates that aliphatic and aromatic units create new type of crystallites. It can be also seen that in case of the polymers of higher molar mass $T_{g}$ increases significantly (Table 3 , run 4 and 8 ).

Thermal characteristics of the obtained aliphatic-aromatic poly(alkylene terephthalate-co-carbonate)s based on different diols are collected in Table 4. With the increasing length of aliphatic hydrocarbon chain due to the chains flexibility $\mathrm{T}_{\mathrm{g}}$ decrease from $18.9^{\circ} \mathrm{C}$ in case of $\mathbf{T C 4 - 5 0}$ to $-24.1^{\circ} \mathrm{C}$ in case

Table 4 DSC analysis results of poly(alkylene terephthalate-co-carbonate)s

\begin{tabular}{|c|c|c|c|c|c|c|c|c|c|}
\hline Run & Sample & $\begin{array}{l}\mathrm{M}_{\mathrm{w}} \\
\mathrm{g} / \mathrm{mol}\end{array}$ & $\begin{array}{l}\mathrm{T}_{\mathrm{g}} \\
{ }^{\circ} \mathrm{C}\end{array}$ & $\begin{array}{l}\mathrm{T}_{\mathrm{m} 1} \\
{ }^{\circ} \mathrm{C}\end{array}$ & $\begin{array}{l}\Delta \mathrm{H}_{\mathrm{m} 1} \\
\mathrm{~J} / \mathrm{g}\end{array}$ & $\begin{array}{l}\mathrm{T}_{\mathrm{m} 2} \\
{ }^{\circ} \mathrm{C}\end{array}$ & $\begin{array}{l}\Delta \mathrm{H}_{\mathrm{m} 2} \\
\mathrm{~J} / \mathrm{g}\end{array}$ & $\begin{array}{l}\mathrm{T}_{\mathrm{c}} \\
{ }^{\circ} \mathrm{C}\end{array}$ & $\begin{array}{l}\Delta \mathrm{H}_{\mathrm{c}} \\
\mathrm{J} / \mathrm{g}\end{array}$ \\
\hline 1 & TC4-50 & 32790 & 18.9 & - & - & 149.2 & 41.0 & 85.8 & 57.5 \\
\hline 2 & $\mathrm{TC} 4 / 5-67^{\mathrm{a}}$ & 50460 & -14.0 & $51.8^{\mathrm{b}}$ & $3.7^{\mathrm{b}}$ & - & - & $-^{c}$ & $-{ }^{c}$ \\
\hline 3 & TC5-49 & 32240 & -6.7 & $57.6^{\mathrm{b}}$ & $19.0^{\mathrm{b}}$ & - & - & $-^{c}$ & $-{ }^{c}$ \\
\hline 4 & TC6 $/ 4^{-49}$ & 41220 & -10.6 & 69.0 & 33.0 & - & - & $-^{c}$ & $-{ }^{c}$ \\
\hline 5 & $\mathrm{TC} 10 /{ }^{-50}$ & 51315 & -24.1 & $76.2 / 84.2$ & 36.1 & - & - & 38.6 & 43.0 \\
\hline
\end{tabular}

${ }^{\mathrm{a}}$ Molar ratios: BMC4:BMC5=1:1 and 1,4-BDO:1,5-PDO=1:1

${ }^{\mathrm{b}} \mathrm{T}_{\mathrm{m}}$ observed only in a first cycle of measurement

${ }^{\mathrm{c}}$ No crystallization process was observed during the measurement conditions 
of $\mathbf{T C 1 0} /{ }^{-}-\mathbf{5 0}$. The melting point of the polymers is the highest for tetramethylene copolyester $\left(149^{\circ} \mathrm{C}\right)$. In case of usage of other diols (and mixture with 1,4-butanediol) the melting point was shifted to much lower temperature and increases with the increasing number of methylene groups in the hydrocarbon chain from $57.6^{\circ} \mathrm{C}$ for TC5-49 up to $84.2{ }^{\circ} \mathrm{C}$ for TC10/4-50 (Tab. 4, run 3-5).

It should be mentioned that polymers based on 1,5pentanediol (odd number of carbon atoms in a molecule) and mixture of 1,5-pentanediol and 1,4-butanediol crystallize very slowly and during cooling with $10 \mathrm{Kmin}^{-1}$ no crystallization was observed (Table 4, run 2-3). The same phenomenon was observed in case $\mathbf{T C 6} / \mathbf{4}-\mathbf{4 9}$, most probably due to the even less regular polymer structure (Table 4, run 4).

Taking into account that thermal stability is important parameter for synthesis as well as polymer processing, thermogravimetric analysis of poly(tetramethylene terephthalate-cocarbonate)s was performed. Two samples with different content of carbonate units were investigated - TC4-39 and TC477. In both cases two-step degradation process was observed (Fig. 10). Based on DTG curve the decomposition temperature at $5 \%$ weight loss $\left(\mathrm{T}_{5 \%}\right)$, the temperature of the highest degradation rate of each step of degradation $\left(T_{\max 1}, T_{\max 2}\right)$, the temperatures after the first $\left(T_{1}\right)$ and the second $\left(T_{2}\right)$ degradation step as well the weight loss of the sample at $T_{1}$ and $T_{2}$ were estimated. In Table 5 weight loss of the sample at $600{ }^{\circ} \mathrm{C}$ $\left(\mathrm{T}_{600}\right)$ was also shown.

The $\mathrm{T}_{5 \%}$ is higher in case of TC4-39, what indicated that thermal stability is increasing with the increasing amount of aromatic units. As it can be observed from the values of weight loss at $T_{1}$ and $T_{2}$ (Table 5) the first step of the degradation is connected to the carbonate units of the polymer chains, and the second step to the terephthalate units. The temperature at which degradation is completed is influenced by the aromatic ester content in the molecule. The $\mathrm{T}_{\max 1}$ and

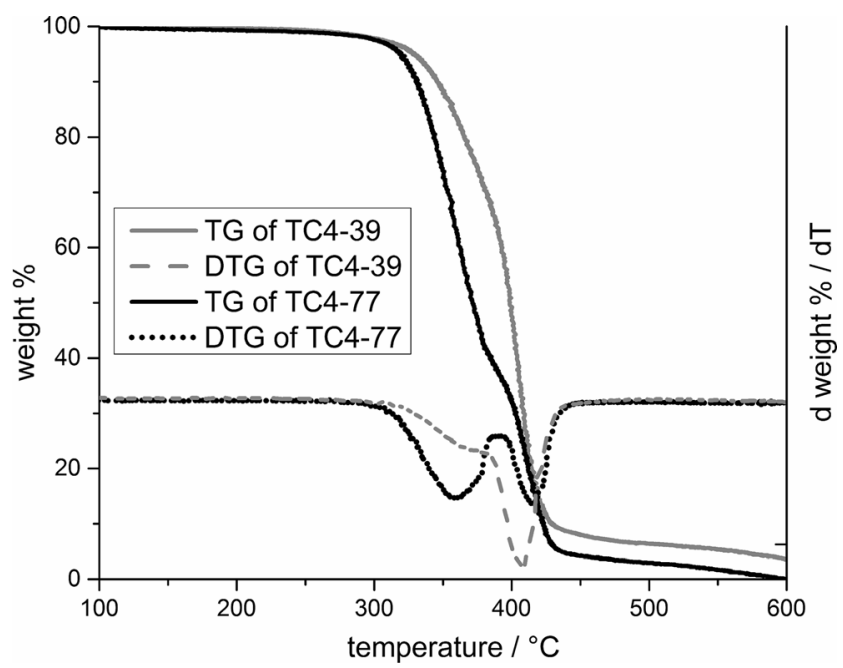

Fig. 10 TGA thermodiagrams of TC4-39 and TC4-77
Table 5 TGA measurement results of PBTC samples with different amount of carbonate units

\begin{tabular}{|c|c|c|c|c|c|c|c|}
\hline Run & Sample & $\begin{array}{l}\mathrm{T}_{5 \%} \\
{ }^{\circ} \mathrm{C}\end{array}$ & $\begin{array}{l}\mathrm{T}_{\max 1} \\
{ }^{\circ} \mathrm{C}\end{array}$ & $\begin{array}{l}\mathrm{T}_{\max 2} \\
{ }^{\circ} \mathrm{C}\end{array}$ & $\begin{array}{l}\text { Weight } \\
\text { loss at } \mathrm{T}_{1} \\
\text { wt. } \%\end{array}$ & $\begin{array}{l}\text { Weight } \\
\text { loss at } \mathrm{T}_{2} \\
\text { wt. } \%\end{array}$ & $\begin{array}{l}\text { Weight loss } \\
\text { at } 600{ }^{\circ} \mathrm{C} \\
\text { wt. } \%\end{array}$ \\
\hline 1 & TC4-39 & 328 & 353 & 406 & 75 & 9 & 4 \\
\hline 2 & TC4-77 & 309 & 349 & 407 & 41 & 5 & 0 \\
\hline
\end{tabular}

$\mathrm{T}_{\max 2}$ values were almost the same in case of both investigated polymers.

Mechanical properties

Preliminary results of mechanical properties of poly(tetramethylene terephthalate-co-carbonate) of different content of carbonate units in molecules are presented in Table 6. The values of Young's modulus (E), the relative elongation at break $\left(\varepsilon_{\text {break }}\right)$, tensile strength $\left(\sigma_{\text {break }}\right)$ and the stress at yield $\left(\sigma_{\text {yield }}\right)$ (if any) were measured. As can be seen aliphatic-aromatic poly(tetramethylene phthalate-co-carbonate)s exhibit good mechanical strength. The tensile strength of 37 and $27 \mathrm{MPa}$ and elongation at break of 690 and $610 \%$, respectively were recorded for copolymers containing 43 and 39 mol.\% of carbonate units (Table 6, runs 3 and 4). During the stretching of these polymer samples orientation of polymer chains was observed - samples changed from white to transparent. Higher amount of carbonate units in the polymer leads to lower tensile strength. It should be mentioned that these samples are characterized by lower molar mass.

Mechanical properties of poly(tetramethylene terephthalate-co-carbonate) TC4-43 are very similar to those of commercially available (BASF) aliphatic-aromatic copolyester Ecoflex $^{\circledR}$ which contains $50 \%$ of adipate and $50 \%$ of terephthalate units (Table 6, runs 3 and 7). It is worth mentioning that the poly(ester-carbonate) containing $40-45 \%$ of butylene

Table 6 Mechanical properties of poly(tetramethylene phthalate-cocarbonate)s with different amount of tetramethylene carbonate units

\begin{tabular}{|c|c|c|c|c|c|c|}
\hline Run & Sample & $\begin{array}{l}\sigma_{\text {yield }} \\
\mathrm{MPa}\end{array}$ & $\begin{array}{l}\sigma_{\text {break }} \\
\mathrm{MPa}\end{array}$ & $\begin{array}{l}\varepsilon_{\text {break }} \\
\%\end{array}$ & $\begin{array}{l}\mathrm{E} \\
\mathrm{MPa}\end{array}$ & $\begin{array}{l}\mathrm{M}_{\mathrm{w}}{ }^{\mathrm{a}} \\
\mathrm{g} / \mathrm{mol}\end{array}$ \\
\hline 1 & TC4-77 & - & $6.0 \pm 1.2$ & $222 \pm 23$ & $1180 \pm 20$ & 27400 \\
\hline 2 & TC4-57 & - & $9.3 \pm 1.3$ & $183 \pm 17$ & $750 \pm 110$ & 18600 \\
\hline 3 & TC4-43 & $25 \pm 1$ & $37 \pm 2$ & $693 \pm 15$ & $670 \pm 170$ & 32000 \\
\hline 4 & TC4-39 & $19 \pm 1$ & $27 \pm 1.5$ & $610 \pm 32$ & $740 \pm 80$ & 18100 \\
\hline 5 & TC5-49 & - & $6.7 \pm 0.4$ & $543 \pm 54$ & - & 32250 \\
\hline 6 & TC6/4-49 & - & $18.4 \pm 1.9$ & $796 \pm 30$ & - & 41200 \\
\hline 7 & Ecoflex $^{\circledR}$ & - & $36^{\mathrm{b}}$ & $550^{\mathrm{b}}$ & $460 \pm 60^{b}$ & nd \\
\hline
\end{tabular}


carbonate units are characterized also by similar thermal properties to Ecoflex ${ }^{\circledR}\left(\mathrm{T}_{\mathrm{m}}=115^{\circ} \mathrm{C}\right)[39]$.

In case of products based on longer diols (1,5-pentanediol, TC5-49 and mixture of 1,6-hexanediol and 1,4-butanediol, TC6/4-49) mechanical properties were also measured (Table 6, runs 5 and 6). In both cases the tensile strength was lower than that when 1,4-butanediol was used. The lower strength was observed because of the polymer poor crystallization capacity caused by usage of diol with odd number of methylene groups as well as a mixture of two different diols.

More detailed results indicating the influence of the content of crystalline phase on mechanical properties of poly(alkylene phthalate-co-carbonate) will be published later.

\section{Conclusion}

Two reaction pathways for synthesis of high molar mass aliphatic-aromatic poly(ester-carbonate)s were elaborated. Copolymers obtained by polycondensation process were characterized by a random chemical structure. Simple organic carbonates such as dimethyl carbonate and propylene carbonate were used as carbonate linkage sources and dimethyl terephthalate as the precursor of ester linkages. To adjust the carbonate units content in the copolymer solid alkylene bis(methylcarbonate) was used as a semiproduct instead of volatile dimethyl carbonate. It was demonstrated that in case of using high boiling point cyclic carbonate as a starting material the process can be carried out in one pot without the need for isolation of the semiproduct. The obtained copolymers containing ca. $50 \mathrm{~mol} \%$ of carbonate units exhibited better mechanical strength $(37 \mathrm{MPa})$ than commercially available aliphatic-aromatic copolyester Ecoflex ${ }^{\circledR}$ keeping the thermal properties at the same level. Due to random structure, these poly(ester-carbonate)s containing less than $50 \mathrm{~mol} \%$ of aromatic units are expected to be biodegradable [40].

Acknowledgments Project was co-financed by the European Union European Regional Development Fund under Operation Program Innovative Economy-MARGEN (POIG.01.03.01-00-018/08) and BIOPOL (POIG.01.01.02-10-025/09). Research has been also supported by the European Union in the framework of European Social Fund (34/ES/ZSIII/W-POKL/14).

Open Access This article is distributed under the terms of the Creative Commons Attribution License which permits any use, distribution, and reproduction in any medium, provided the original author(s) and the source are credited.

\section{References}

1. Inoue S, Koinuma H, Tsuruta T (1969) J Polym Sci B Polym Phys 7: 287-292
2. Kuran W, Pasynkiewicz S, Skupinska J, Rokicki A (1976) Makromol Chem 177:11-20

3. Rokicki A, Kuran W (1981) J Macromol Sci Rev Macromol Chem C21:153-186

4. Lu X-B, Darensbourg DJ (2012) Chem Soc Rev 41:1462-1484

5. Darensbourg DJ, Wilson SJ (2012) Green Chem 14:2665-2671

6. Luinstra GA (2008) Polym Rev 48:192-219

7. Tang L, Xiao M, Xu Y, Wang W, Meng Y (2013) J Polym Res 20:190

8. Zhou T, Zou Z, Gan J, Chen L, Zhang M (2011) J Polym Res 18: 2071-2076

9. Pawlowski P, Rokicki G (2004) Polymer 45:3125-3137

10. Tomczyk KM, Parzuchowski PG, Kozakiewicz J, Przybylski J, Rokicki G (2010) Polimery 55:366-372

11. Tomczyk KM, Parzuchowski PG, Rokicki G (2011) J Appl Polym Sci 120:683-691

12. Pospiech D, Komber H, Jehnichen D, Hussler L, Eckstein K, Scheibner H, Janke A, Kricheldorf HR, Petermann O (2005) Biomacromolecules 6:439-446

13. Kricheldorf HR, Rost S (2005) Macromolecules 38:8220-8226

14. Yang J, Liu F, Yang L, Li S (2010) Eur Polym J 46:783-791

15. Xu J, Liu Z-L, Zhuo RX (2006) J Appl Polym Sci 101:1988-1994

16. Wolinsky JB, Ray WC III, Colson YC, Grinstaff MW (2007) Macromolecules 40:7065-7068

17. Guan H, Zhigang Xie Z, Tang Z, Xu X, Chen X, Jing X (2005) Polymer 46:2817-2824

18. Zhou Y, Wu GL, Zhuo RX, Liu ZL (2009) Eur Polym J 45:18681872

19. Yang J, Tian W, Li Q, Li Y, Amin CA (2004) Biomacromolecules 5: $2258-2268$

20. Vincenzi V, Ferruti P, Ford J, Duncan R (2001) Macromol Biosci 1: 164-169

21. Okada M, Yokoe M, Aoi K (2002) J Appl Polym Sci 86:872-880

22. Miura M, Watanabe H, Fujimori T, Isahaya S (1995) Jap. Pat. 07053695(A2)

23. More AS, Palaskar DV, Cloutet E, Gadenne B, Alfos C, Cramail H (2011) Polym Chem 2:2796-2803

24. Paturej M, El Fray M (2009) Polimery 54:611-617

25. Liu Y, Ranucci E, Lindblad MS, Albertsson AC (2001) J Polym Sci A Polym Chem 39:2508-2519

26. Yokoe M, Okada M, Aoi K (2003) J Polym Sci A Polym Chem 41: 2312-2321

27. Yokoe M, Aoi K, Okada M (2005) J Appl Polym Sci 98:1679-1687

28. Artham T, Doble M (2008) Macromol Biosci 8:14-24

29. Zhu KJ, Hendren RW, Jensen K, Pitt CG (1991) Macromolecules 24: 1736-1740

30. Li F, Luo S, Yu J (2010) J Polym Res 17:279-287

31. Luo S, Li F, Yu J (2011) J Polym Res 18:393-400

32. Witt U, Mueller RJ, Deckwer WD (1996) J Environ Polym Degr 4:9-20

33. Mazurek MM, Tomczyk KM, Rokicki G (2014) Polym Adv Technol 25:1273-1284

34. Rokicki G, Brulinski T, Tomczyk KM, Mazurek MM, Parzuchowski PG (2012) World Polymer Congress MACRO 2012. Blacksburg, Virginia

35. Kricheldorf HR, Mahler A (1996) J Polym Sci A Polym Chem 34: 2399-2406

36. Su W, Feng J, Wang H-F, Zhang X-Z, Zhuo R-X (2010) Polymer 51: 1010-1015

37. Mazurek MM, Parzuchowski PG, Rokicki G (2014) J Appl Polym Sci 131:39764

38. Yamadera R, Murano N (1967) J Polym Sci 5:2259-2268

39. http://www.plasticportal eu.ecoflex

40. Mazurek MM, Rokicki G (2013) Pol J Chem Technol 15:80-88 